\title{
RECENT DEVELOPMENTS IN INDIANA TAXATION SURVEY 2016
}

\author{
LAWRENCE A. JEGEN III* \\ PETER PRESCOTT ${ }^{* *}$ \\ JUSTIN W. JONES ${ }^{* * *}$
}

\section{InTRODUCTION: SOME REFERENCES USED IN THIS ARTICLE}

This Article highlights the major tax developments that occurred during the 2016 calendar year. Whenever the term "GA" is used in this Article, the term refers only to the 119th Indiana General Assembly. Whenever the term "Tax Court" is referred to, such term refers only to the Indiana Tax Court. Whenever the term "Court of Appeals" is referred to, the term refers only to the Indiana Court of Appeals. Whenever the term "DLGF" is used, the term refers only to the Indiana Department of Local Government Finance. Whenever the term "IBTR" is used, the term refers only to the Indiana Board of Tax Review. Whenever the term "Department" or "DOR" is used, the term refers only to the Indiana Department of State Revenue. Whenever the term "IC" or "Indiana Code" is used, the term refers only to the Indiana Code, which is in effect at the time of the publication of this Article, unless otherwise explicitly stated. Whenever the term "ERA" is used, the term refers only to an Indiana Economic Revitalization Area. Whenever the term "CAGIT" is used, the term refers only to the Indiana County Adjusted Gross Income Tax. Whenever the term "COIT" is used, the term refers only to the Indiana County Option Income Tax. Whenever the term "LOIT" is used, the term refers only to the Local Option Income Tax. Whenever the term "IEDC" is used, the term refers only to the Indiana Economic Development Corporation. Whenever the term "CEDIT" is used, the term refers only to the Indiana County Economic Development Income Taxes. Whenever the term "IRC" or "Code" is used, the term refers only to the Internal Revenue Code, which is in effect at the time of the publication of this Article. Whenever the term "section" is used in this Article, the term refers only to a section of the Indiana Code, unless the reference is clearly to the Internal Revenue Code. Whenever the term "Public Law" is used, the term only refers to legislation passed by the Indiana General Assembly and assigned a Public Law number. Whenever the term "PTABOA" is used, the term refers only to a Property Tax Assessment Board of Appeals.

* Thomas F. Sheehan Professor of Tax Law and Policy, Indiana University Robert H. McKinney School of Law. L.L.M., 1963, New York University; M.B.A., J.D., 1959, University of Michigan; B.A., 1956, Beloit College.

** Associate Professor of Business Law, Butler University Andre B. Lacy School of Business. J.D., 2006, University of Houston Law Center; M.P.A., 1999, University of Texas at Austin; M.S., 1993, University of Chicago; B.A., 1992, Augustana College.

*** J.D. Candidate, 2018, Indiana University Robert H. McKinney School of Law; B.S., 2011, Indiana University East.

http://doi.org/10.18060/4806.1174 


\section{INDiAna General AsSEMbly Legislation}

Short-session years often yield fewer state and local tax legislative changes and 2016 was no exception. Although the 119 th General Assembly did pass a number of Public Laws affecting taxation last spring, the session lacked the major changes seen in recent years. ${ }^{1}$ Nevertheless, the revisions will be important to Indiana taxpayers in the future. This Part discusses those revisions and highlights the majority of the GA's changes from 2016 in the areas of property taxes, state gross retail and use taxes, state income taxes, local taxes, death taxes, excise taxes, and tax administration.

\section{A. Property Taxes}

Once again, property tax legislation made up the bulk of the GA's tax-related activity in 2016. And, once again much that work dealt with mundane matters like statutory housekeeping, ${ }^{2}$ definitional fine tuning, ${ }^{3}$ filing deadlines,${ }^{4}$ filing methods, ${ }^{5}$ trial court jurisdiction, ${ }^{6}$ assessment appeal procedures, ${ }^{7}$ budgetary

1. See, e.g., Lawrence A. Jegen III et al., Recent Developments in Indiana Taxation Survey 2015, 49 IND. L. REV. 1235, 1252-55 (2016) [hereinafter Jegen et al., 2015] (reporting the GA's overhaul of Indiana's local income taxation system); Lawrence A. Jegen III et al., Recent Developments in Indiana Taxation Survey 2013, 47 IND. L. REV. 1173, 1174 (2014) [hereinafter Jegen et al., 2013] (reporting the GA's repeal of Indiana's inheritance taxes).

2. See, e.g., Pub. L. No. 149-2016, § 20, 2016 Ind. Acts 1418, 1445-46 (amending IND. CODE $\S$ 6-1.1-4-43 to correct some minor typographical errors, such as the removal of an extraneous "to"); Pub. L. No. 197-2016, § 8, 2016 Ind. Acts 2232, 2237 (amending IND. CodE § 6-1.1-10.3-2 to properly reflect the 2015 wholesale revision of Indiana's local income tax regime); Pub. L. No. 203-2016, § 9, 2016 Ind. Acts 2910, 2928-29 (repealing IND. CoDE § 6-1.1-18.5-7 which contained now-obsolete rules governing 2014-2016 levy limits).

3. See, e.g., Pub. L. No. 202-2016, § 6, 2016 Ind. Acts 2903, 2907-08 (amending Ind. CodE $\S$ 6-1.1-12-26.2 to limit the "heritage barn" definition to certain "mortise and tenon barn[s]," which are defined as "barn[s] that [were] built using heavy wooden timbers, joined together with woodpegged mortise and tenon joinery").

4. See, e.g., Pub. L. No. 203-2016, § 6, 2016 Ind. Acts at 2924-27 (amending IND. CodE $\S$ 6-1.1-12.1-5.3 to extend the start of the window for filing late rehabilitation or redevelopment deduction applications (i.e., applications not made in the year the property owner initially occupies the eligible vacant building) from March 1 to January 1).

5. See, e.g., Pub. L. No. 199-2016, § 1, 2016 Ind. Acts 2889, 2889-90 (amending Ind. CodE $\S 6-1.1-3-7.2$ to require a taxpayer with exempt business personal property to file a return indicating the property is exempt instead of doing so in a notarized certification given to the county assessor).

6. See, e.g., Pub. L. No. 84-2016, §§ 28-32, 2016 Ind. Acts 745, 757-62 (amending IND. CODE $\S \S 6-1.1-10-11,-18.5-12,-23-1,-23-2$, and $-36-4$ to give the superior courts and the probate courts concurrent jurisdiction with the circuit courts over certain property matters).

7. See, e.g., Pub. L. No. 196-2016, §§ 1-3, 2016 Ind. Acts 2228, 2228-32 (amending IND. CODE $\S \S 6-1.1-11-7,-15-3$, and -15-12 to allow taxpayers an additional fifteen days to petition the IBTR for review of a PTABOA's rejection of an exemption petition and, if the PTABOA fails to act on the taxpayer's exemption petition or petition to correct errors within 180 days after either 
procedures, ${ }^{8}$ administrative roles, ${ }^{9}$ geographically-targeted measures, ${ }^{10}$ taxpayerspecific relief, ${ }^{11}$ and property-transfer procedures. ${ }^{12}$

During 2016, the GA did focus on a few property tax areas. First, the GA made a number of changes to the assessment procedures for various types of real property. Specifically, the GA amended the annual assessment adjustment process for real property that is not fully reassessed under another provision..$^{13}$ The annual adjustment process employs a final base rate determined by the DLGF using specified statutory rates and a calculated preliminary base rate, which depends on a rolling average of the six most recent years. ${ }^{14}$ The GA also created a special rule requiring the reassessment of a real property improvement that was part of a "covered project" "by carrying out a physical inspection of the property" no later

petition is filed with the PTABOA, to permit the IBTR to hear the taxpayer's petition without a decision by the PTABOA).

8. See, e.g., Pub. L. No. 184-2016, §§ 11, 19-20, 2016 Ind. Acts 2009, 2026-30, 2038-39 (amending IND. CODE $\S \S 6-1.1-17-16,-18.5-24$, and -20.6-11.1 to revise the budgetary process for political subdivisions, including the DLGF's role in certifying each political subdivision's budget, tax rate, and tax levy and its responsibility to provide each taxing unit with estimates of that unit's maximum permissible property tax levies and property tax distributions); Pub. L. No. 180-2016, $\S 11,2016$ Ind. Acts 1897, 1906-07 (codified at IND. CODE § 6-1.1-18.5-25 to replace a municipality's normal ad valorem property tax levy limits with a higher one when the municipality's assessed value growth exceeds a statutory threshold and its population increased at least $150 \%$ between the last two decennial censuses).

9. See, e.g., Pub. L. No. 111-2016, §§ 2-4, 2016 Ind. Acts 1053, 1055 (amending IND. CodE $\S \S 6-1.1-6-12,-13$, and -23 to reassign certain responsibilities for assessing forest lands from the county auditor to the county assessor).

10. See, e.g., Pub. L. No. 127-2016, § 1, 2016 Ind. Acts 1227, 1227-28 (amending IND. CodE $\S 6-1.1-20.3-26.9$ to deal with unique circumstances affecting only the Gary Community School Corporation); Pub. L. No. 180-2016, § 12, 2016 Ind. Acts at 1907 (amending IND. CoDE § 6-1.118.5-26 to permit the executive of Howard Township in Washington County to request an increase in the maximum ad valorem property tax levy).

11. See, e.g., Pub. L. No. 190-2016, § 1, 2016 Ind. Acts 2150, 2150 (amending IND. CodE $\S 6-1.1-12-17.9$ to permit a trust that owns real property to claim deductions tied to the status of the trust's beneficiary who occupies the property provided the individual would otherwise qualify for the deduction (e.g., the occupying beneficiary is elderly, blind, disabled, or a partially-disabled veteran)).

12. See, e.g., Pub. L. No. 198-2016, § 18, 2016 Ind. Acts 2399, 2413-14 (amending IND. CODE $§ 6-1.1-7-10$ to clarify that the county treasurer's duty to issue a move permit for a mobile home does not take effect until the taxes, special assessments, interest, penalties, judgments, and costs that are due and payable are paid); id. § 20, 2016 Ind. Acts at 2414 (amending IND. CODE $\S$ 6-1.1-7-11 to extend the window covered by a mobile home moving permit from thirty days to ninety days).

13. Pub. L. No. 180-2016, § 2, 2016 Ind. Acts at 1897-99 (amending IND. CoDE § 6-1.1-4$4.5)$.

14. Id. 
than January 1 of the year after the year in which the project was completed. ${ }^{15}$ For this purpose, a "covered project" is the "construction, remodeling, redevelopment, rehabilitation or repair of any ... real property improvement" by a private person using public funds (at least in part), where the resulting property improvement is owned by a private person. ${ }^{16}$

More generally, the GA clarified that "true tax value does not mean the value of the property to the user" for real property tax assessments, and that true tax value of improved property must take into account market segmentation such that "a valuation does not reflect the true tax value ... if the purportedly comparable sale properties supporting the valuation have a different market or submarket than the current use of the improved property, based on a market segmentation analysis." ${ }^{17}$ Regarding specific types of real property, the GA made the following changes:

- eliminated the special rules for determining the true tax value of real property that "is a limited market or special purpose property that would commonly be regarded as a big box retail building"; ${ }^{18}$

- eliminated the special rules for determining the true tax value of "commercial nonincome producing real property, including sale-leaseback property"; ${ }^{19}$

- required use of the soil productivity factors from the March 1, 2011 assessment date for agricultural land assessments on January 1, 2016 and each assessment date thereafter; ${ }^{20}$ and

- $\quad$ set the per acre value of native forest land, forest plantations, wildlands, windbreak land, and filter strip land at $\$ 13.29$ on January 1, 2017 and indexed that amount for inflation in later years. ${ }^{21}$

The GA's second major property tax initiative involved helping counties cut

15. Pub. L. No. 205-2016, § 1, 2016 Ind. Acts 3021, 3021-22 (codified at IND. CodE $§ 6-1.1-$ 4-4.8).

16. $I d$.

17. Pub. L. No. 204-2016, § 13, 2016 Ind. Acts 2958, 2989-91 (amending Ind. CodE $§ 6-1.1-$ 31-6).

18. Id. $\S 10,2016$ Ind. Acts at 2987-88 (repealing IND. CODE $§ 6-1.1-4-43$ ). This short-lived statutory provision was added to the Indiana Code in 2015. See Jegen et al., 2015, supra note 1, at 1237 (discussing the new rules for big box retail buildings).

19. Pub. L. No. 204-2016, § 11, 2016 Ind. Acts at 2988-89 (repealing IND. CoDE § 6-1.1-444). Like the big box retail store provision discussed in the preceding footnote, this provision was created in 2015. See Jegen et al., 2015, supra note 1, at 1237 (discussing the addition of new rules for commercial nonincome producing real property).

20. Pub. L. No. 180-2016, § 3, 2016 Ind. Acts 1897, 1899-1901 (amending IND. CodE § 61.1-4-13).

21. Pub. L. No. 180-2016, $\S \S 5-7,2016$ Ind. Acts 1897, 1901-03 (amending IND. CoDE $\S \S$ 6-1.1-6-14, -6.2-9, and -6.7-9). The annual inflation adjustment will use the Consumer Price Index for All Urban Consumers. Id. Ditch assessments are still due for windbreak land and filter strip land. Id. $\S \S 6-7,2016$ Ind. Acts at 1902-03 (amending IND. CoDE $\S \S 6-1.1-6.2-9$ and -6.7-9). 
administrative costs by permitting groups of them to create a multiple-county PTABOA that covers the entire geographic area of the participating counties. ${ }^{22}$ The adopting counties must pass substantially similar appointment ordinances that create a common board of either three or five members who satisfy the requisite statutory requirements (e.g., a majority must have obtained a level two or level three assessor-appraiser certification). ${ }^{23}$ Administrative support duties for the multiple-county PTABOA fall to the county assessor in the county with the greatest population. ${ }^{24}$ The related costs, and other joint costs (e.g., the board members' compensation and per diem compensation), must be divided up among the participating counties as agreed upon in the multiple-county PTABOA's founding ordinance. ${ }^{25}$ When a multiple-county PTABOA comes into existence, the PTABOAs that it replaces must stay all filed or pending proceedings and transfer them to the new multiple-county PTABOA. ${ }^{26}$

A number of property tax exemptions and deductions were modified during the session. Homeowners associations now receive an exemption for tangible personal property that is held for the use or benefit of their members. ${ }^{27}$ In addition, the GA broadened the definition of "land used for public airport purposes" that may qualify for a property tax exemption to include leased property used for agricultural purposes if that property is located within the federally-restricted area needed for normal airport operations, runway protection zones, avigation easements, etc. ${ }^{28}$ At the same time, the GA took steps to terminate the exemption for nonprofit organizations that acquire land for the purpose of building or renovating a single-family home before transferring that home in a charitable manner to a low-income individual, effective January 2, 2017. ${ }^{29}$ For assessment dates falling after December 31, 2017, low-

22. Pub. L. No. 207-2016, § 4, 2016 Ind. Acts 3039, 3043 (codified at IND. CoDE $§ 6-1.1-28-$ 0.1 ). Many of the existing rules applicable to single-county PTABOAs apply to the new multiplecounty PTABOAs because the GA expanded the existing "county property tax assessment board of appeals" definition to cover multiple-county PTABOAs. Id. $\S 1,2016$ Ind. Acts at 3039-40 (amending IND. CODE $\S 6-1.1-4-4.5$ ). To cover any gaps, the multiple-county PTABOA is empowered with all powers "necessary or convenient to carry out this chapter" (i.e., chapter 28, which is titled "County Property Tax Assessment Board of Appeals"). Id. § 11, 2016 Ind. Acts at 3047 (codified at IND. CODE $§ 6-1.1-28-0.8$ ).

23. Id. $\S \S 5,7,2016$ Ind. Acts at 3043-45 (codified at IND. CODE $\S \S 6-1.1-28-0.2$ and -0.4).

24. Id. $\S 8,2016$ Ind. Acts at 3045 (codified at IND. CODE $\S 6-1.1-28-0.5$ ).

25. Id. $\S \S 6,8,17,2016$ Ind. Acts at 3044-45, 3052 (codified at IND. CoDE $\S \S 6-1.1-28-0.3$, -0.5 , and -8$)$.

26. Id. $\S 10,2016$ Ind. Acts at 3046-47 (codified at IND. CODE $\S 6-1.1-28-0.7$ ).

27. Pub. L. No. 203-2016, § 2, 2016 Ind. Acts 2910, 2911-12 (codified at IND. CodE § 6-1.110-37.8).

28. Pub. L. No. 180-2016, § 8, 2016 Ind. Acts 1897, 1903-04 (amending Ind. CodE $§ 6-1.1-$ 10-15).

29. Pub. L. No. 181-2016, § 2, 2016 Ind. Acts 1924, 1925-29 (amending IND. CodE § 6-1.110-16). The GA also revised the exemption that applies to assessment dates before January 2, 2017 to remove the four-year time limit and to provide that a nonprofit that holds the property for more 
income real property is exempt if it had qualified for exempt status for one or more assessments prior to that date or it satisfies one of three other requirements (e.g., a political subdivision has passed an affordable housing resolution covering the property). ${ }^{30}$

The deduction for rehabilitated property also terminated on January 2, 2017, but qualifying rehabilitated property (as of that date) may continue to receive a deduction that is not adjusted for post-January 1, 2017 increases in its assessed value due to the rehabilitation. ${ }^{31}$ Property tax deductions for current and former military service members were adjusted, too. The eligibility cap on the deduction for totally-disabled veterans and partially-disabled veterans age sixty-two or over was increased to $\$ 175,000$ for the January 1, 2017 assessment date and the property relevant in determining whether that cap is exceeded was limited to Indiana real property, mobile homes, and manufactured homes. ${ }^{32}$ In addition, the GA created a new homestead exemption for veterans who were honorably discharged after at least ninety days of service, are at least fifty percent disabled, and who received their homestead for free from an IRC tax-exempt organization. ${ }^{33}$ The exemption's value scales with the veteran's disability percentage. ${ }^{34}$ Active-duty service members will continue to qualify for the standard homestead deduction even though the property is leased while the service member is away from Indiana on active duty, so long as the service member has lived in the property at any time during the past ten years. ${ }^{35}$ For all taxpayers, the county auditor now has up to three years from the property tax's original due date to notify a taxpayer of additional taxes, penalties, and interest resulting from an improper receipt of a standard deduction for a homestead. ${ }^{36}$ The taxpayer must make full payment of the amount owed within one year if the taxpayer received the improper standard deduction despite failing to return a homestead verification form. ${ }^{37}$ If the taxpayer did submit an incorrect homestead verification form, then full payment is required within thirty days. ${ }^{38}$

Although the GA could not resist tinkering with the real property tax sale provisions in 2016, the modifications were modest. An administrative change from last year, which permitted omission of the property description from

than eight years, or that transfers it to someone other than a low-income individual, must pay all the taxes that would have been due if the property had never been exempt. Id.

30. Id. $\S 3,2016$ Ind. Acts at 1930 (amending IND. CODE $\S 6-1.1-10-16.7$ ).

31. Id. $\S 4,2016$ Ind. Acts at 1931-32 (amending IND. CoDE $\S 6-1.1-12-18$ ).

32. Pub. L. No. 100-2016, § 1, 2016 Ind. Acts 968, 968-70 (amending Ind. CodE § 6-1.1-1214).

33. Id. $\S 2,2016$ Ind. Acts at 970-71 (codified at IND. CODE $§ 6-1.1-12-14.5$ ).

34. Id.

35. Id. $\S 3,2016$ Ind. Acts at 971-81 (amending IND. CODE $\S 6-1.1-12-37$ ).

36. Pub. L. No. 203-2016, § 15, 2016 Ind. Acts 2910, 2940-43 (amending InD. CodE § 6-1.136-17).

37. Id. In this case, no penalties or interest are due.

38. Id. 
subsequent tax sale notices when the property was not sold in its first tax sale, ${ }^{39}$ was extended to the sale of vacant or abandoned property ${ }^{40}$ and of tax sale certificates. ${ }^{41}$ The same administrative approach now applies to the transfer of property or tax sale certificates to nonprofit entities ${ }^{42}$ and to transfers of property in which the county executive has a lien to someone able to repair and maintain it. ${ }^{43}$ In addition, the GA extended the DLGF's power to cancel property taxes on real property that becomes owned by the state or a government entity (e.g., a city) to also cover "delinquencies, fees, special assessments, and penalties," regardless of whether those amounts were assessed while the state or government entity owned the property. ${ }^{44}$ Those cancellations do not relieve the liability of anyone who is personally liable for the cancelled amounts by virtue of owning the property before the state or government entity acquired it. ${ }^{45}$ Finally, the GA clarified that a buyer who purchased the right to redeem property from the original owner during the redemption period must include the tax sale surplus fund amount when determining the buyer's redemption payment amount. ${ }^{46}$

In 2015, the GA created a new chapter to the Indiana Code addressing serial tax delinquencies. ${ }^{47}$ This year, the GA corrected some minor errors in that earlier work. ${ }^{48}$ The GA also replaced the requirement that the property be "on the tax sale list" with "eligible for tax sale," delinquencies petition only needs to be served on each person having a "substantial property interest of public record in any of the tracts or items of real property." ${ }^{\circ 0}$ The timing of the court hearing addressing the petition must now fall between thirty and sixty days after the petition is filed with the court, and each

39. Jegen et al., 2015, supra note 1, at 1241 n.47. The GA updated its 2015 changes to bring them in line with the new language adopted for other tax sale notices in 2016. Pub. L. No. 1872016, § 2, 2016 Ind. Acts 2094, 2096-98 (amending IND. CODE § 6-1.1-24-3).

40. Pub. L. No. 187-2016, § 1, 2016 Ind. Acts at 2094-96 (amending IND. CodE § 6-1.1-24$1.5)$.

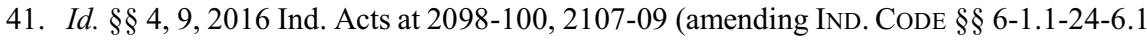
and -17).

42. Id. $\S 5,2016$ Ind. Acts at 2100-02 (amending IND. CODE $\S 6-1.1-24-6.7$ ).

43. Id. $\S 6,2016$ Ind. Acts at 2102-04 (amending IND. CODE $\S 6-1.1-24-6.9$ ).

44. Id. $\S 12,2016$ Ind. Acts at 2111-14 (amending IND. CoDE $\S 6-1.1-36-7$ ).

45. Id.

46. Id. $\S \S 10-11,2016$ Ind. Acts at 2109-11 (amending IND. CODE $\S \S 6-1.1-25-1$ and -2).

47. See Jegen et al., 2015, supra note 1, at 1242 (reporting the creation of IND. CoDE § 6-1.124.5 (Determination of Serial Tax Delinquencies)).

48. See, e.g., Pub. L. No. 183-2016, § 2, 2016 Ind. Acts 1994, 1995-96 (amending Ind. CodE $\S 6-1.1-24.5-3$ to correct some typographical errors and to revise the serial tax delinquencies petition requirements to include a statement that the petitioner will receive a deed free of any right of redemption unless the property taxes and special assessments that accrue after certification as eligible for tax sale are paid before the court hearing date and time).

49. Id. $\S 1,2016$ Ind. Acts at 1994-95 (amending IND. CODE § 6-1.1-24.5-2).

50. Id. $\S 3,2016$ Ind. Acts at 1996 (amending IND. CODE $\S 6-1.1-24.5-4$ ). Prior to the amendment, the petition also had to be served upon "any other appropriate party." Id. 
owner of record must appear to show cause as to why the petition is invalid. ${ }^{51}$ After a finding that serial tax delinquencies exist, the county assessor must remove the taxes and special assessments that triggered the tax sale, and "all subsequent taxes, special assessments, interest, penalties, and costs of sale, from the tax duplicate" using the certificate of error procedures that apply to taxes. ${ }^{52}$

\section{B. State Gross Retail and Use Taxes}

Not much happened in the state gross retail and use tax area during 2016. For individuals, one of the bigger items was the GA's decision to treat those who rent or furnish "rooms, lodgings, or accommodations" located in "a house, condominium, or apartment in which rooms, lodgings, or accommodations are rented or furnished for transient residential housing for consideration" within Indiana, and the facilitators who connect those providers to their customers (e.g., Airbnb and its hosts), as retail merchants who are subject to the state gross retail tax..$^{53}$ In addition to collecting and remitting the tax, the lodging providers and their facilitators must give their customers an itemized statement showing that tax and any part of the fee that goes to the facilitator or face a twenty-five dollar penalty per transaction. ${ }^{54}$

After studying the matter in $2015,{ }^{55}$ the GA decided to exempt from tax any transactions involving the sale or lease of certain gold, silver, and platinum coins minted by the U.S. Treasury; coins issued by the states; gold, silver, platinum, or palladium bullion of sufficient quality; or legal tender. ${ }^{56}$ The rental of storage for qualifying items is also exempt from tax. ${ }^{57}$ Also, the GA created a presumption in favor of a state use tax exemption for tangible personal property sold to a person for use in the provision of qualified public transportation when that person provides a signed affirmation attesting to that use. ${ }^{58}$

Transactions involving tangible personal property used in construction projects also received attention, with many of the changes retroactively effective on January 1, 2010. A contractor who disposes of tangible personal property, or who converts it into real property, under a time and material contract is required

51. Id. $\S 4,2016$ Ind. Acts at 1996-97 (amending IND. CODE § 6-1.1-24.5-5). The former window ran from fifteen to twenty-five days. Id.

52. Id. $\S 5,2016$ Ind. Acts at 1997-98 (amending IND. CODE $\S 6-1.1-24.5-6)$.

53. Pub. L. No. 181-2016, § 19, 2016 Ind. Acts 1924, 1941-42 (amending IND. CodE § 6-2.54-4). For this purpose, a facilitator is a person who markets another's rental lodgings through the Internet to consumers and who accepts payment from those consumers for those lodgings. Id. $\S 16$, 2016 Ind. Acts at 1938-39 (codified at IND. CODE § 6-2.5-1-19.5).

54. Id. $\S 20,2016$ Ind. Acts at 1942 (codified at IND. CoDE $\S 6-2.5-4-4.2$ ).

55. Jegen et al., 2015, supra note 1, at 1245-46.

56. Pub. L. No. 195-2016, § 1, 2016 Ind. Acts 2225, 2225-26 (codified at IND. CodE § 6-2.55-47).

57. Id.

58. Pub. L. No. 204-2016, § 14, 2016 Ind. Acts 2958, 2991-92 (codified at IND. CODE $§ 6-$ $2.5-3-7.5)$. 
to collect and remit the state gross retail tax on that tangible personal property. ${ }^{59}$ Furthermore, while the state use tax does apply to a contractor's purchase of tangible personal property for conversion into real property, the purchase is exempt if the subsequent conversion is covered by a time and material contract. ${ }^{60}$ Finally, the GA removed the "cutting of steel bars into billets" from the list of manufacturing activities that qualify for a state gross retail tax exemption. ${ }^{61}$

\section{State Income Taxes}

After several years of sustained activity, the state income tax area was fairly quiet in 2016. Effective on January 1, 2016, the GA updated its definition of "Internal Revenue Code" to mean the IRC in effect on January 1, 2016, rather than the one in effect on January 1, 2015, and incorporated the Treasury regulations in effect on January 1, 2016, rather than those in effect on January 1, $2015 .^{62}$ The GA also ordered the legislative service agency to study "[t]he combined reporting approach to apportioning income for income tax purposes" and "[i]ssues related to transfer pricing." ${ }^{63}$ In addition, the GA made a handful of minor, unrelated changes.

First, on the education front the GA eliminated the tax credit for contributions to the 21 st Century Scholars Program Support Fund ${ }^{64}$ and established the existence of ABLE accounts that satisfy the requirements for a "qualified ABLE program" under IRC section 529A. ${ }^{65}$ Second, beginning in 2018 an individual who is the legal guardian of a dependent (as that term is defined in IRC section 151(c)) who is less than nineteen years old (or less than twenty-four years old, if

59. Pub. L. No. 181-2016, § 21, 2016 Ind. Acts at 1943 (amending IND. CoDE § 6-2.5-4-9). For this purpose, a contractor is "any person engaged in converting construction material into real property on behalf of another person," $i d$. $§ 15,2016$ Ind. Acts at 1938 (codified at IND. CoDE $\S 6-$ 2.5-1-14.9), and a time and material contact is "a contract in which the cost of construction material and the cost of labor or other charges are stated separately." Id. § 17, 2016 Ind. Acts at 1939 (codified at IND. CODE $\S 6-2.5-1-27.7$ ).

60. Id. $\S 18,2016$ Ind. Acts at 1939-41 (amending IND. CoDE $\S 6-2.5-3-2$ ).

61. Id. $\S 22,2016$ Ind. Acts at 1943-44 (amending IND. CODE $\S 6-2.5-5-3$ ).

62. Pub. L. No. 204-2016, § 15, 2016 Ind. Acts at 2992-93 (amending InD. CodE § 6-3-1-11).

63. Pub. L. No. 185-2016, § 1, 2016 Ind. Acts 2085, 2085-86. The GA made some changes in this area during 2015 and presumably intends to return to it in 2017. See Jegen et al., 2015, supra note 1, at 1248-49 (discussing the GA's revision of the business income definition, elimination of the throwback rule for income sourcing, and adjustment of the rules covering intercompany interest).

64. Pub. L. No. 181-2016, § 24, 2016 Ind. Acts at 1945-55 (amending IND. CoDE § 6-3-3$5.1)$.

65. Pub. L. No. 12-2016, § 8, 2016 Ind. Acts 87, 88-99 (codified at IND. CoDE § 12-11-14). The GA made several conforming amendments in other portions of title 12 in connection with the creation of the ABLE accounts, such as adding the definition of "ABLE account" to the general definitions under title 12. Id. $\S 1,2016$ Ind. Acts at 87 (codified at IND. CoDE $\S 12-7-2-0.5$ ). 
the dependent is also a student) may deduct $\$ 1,500$ for that dependent. ${ }^{66}$ Third, income belonging to a land bank is not subject to state income tax. ${ }^{67}$ Fourth, qualifying acute care hospitals may now carry forward their unused credit for property taxes paid in Indiana on property used as a hospital. ${ }^{68}$ Fifth, a partner's (or trust beneficiary's) payment of unwithheld tax relieves the partnership (or trust or estate) that failed to withhold from liability for that tax, but does not relieve the partnership, trust, or estate from liability for "interest or penalty otherwise due in respect to the failure to withhold." ${ }^{169}$ Finally, the GA simplified income tax compliance for members of non-Indiana-based racing teams by ordering the DOR to permit a composite race team income tax return that exempts individual team members from their filing obligations, provided the composite return cannot result in less tax due. ${ }^{70}$

\section{State Tax Liability Credits}

After three years of reducing the number of available state tax liability credits, ${ }^{71}$ the GA merely tweaked a few credits in 2016 . For example, the GA revised administration of the Economic Development for a Growing Economy Tax Credit, ${ }^{72}$ the Hoosier Business Investment Tax Credit, ${ }^{73}$ and the Hoosier Alternative Fuel Vehicle Manufacturer Tax $\mathrm{Credit}^{74}$ by clarifying that the IEDC, not its president, is responsible for carrying out the IEDC's duties regarding oversight of those tax credits. Furthermore, the IEDC now has sole responsibility for determining whether a taxpayer who qualified for those three credits is in compliance with its accompanying tax credit agreement and, if the taxpayer is not

66. Pub. L. No. 181-2016, § 23, 2016 Ind. Acts at 1944-54 (amending IND. CodE $§ 6-3-1-$ $3.5)$.

67. Pub. L. No. 211-2016, § 1, 2016 Ind. Acts 3079, 3079, 3088 (codified at IND. CoDE $§ 36-$ 7-38-19).

68. Pub. L. No. 181-2016, § 26, 2016 Ind. Acts at 1958 (amending InD. CoDE $\S$ 6-3-3-14.6).

69. Id. $\S \S 27-28,2016$ Ind. Acts at 1958-64 (amending IND. CODE $\S \S 6-3-4-12$ (partnerships) and -15 (trusts or estates)).

70. Pub. L. No. 210-2016, § 1, 2016 Ind. Acts 3076, 3076-78 (amending InD. CodE § 6-3-2$3.2)$.

71. See Jegen et al., 2015, supra note 1, at 1250-51; Lawrence A. Jegen III et al., Recent Developments in Indiana Taxation Survey 2014, 48 IND. L. REV. 1455, 1466 (2015); Jegen et al., 2013, supra note 1 , at 1184.

72. See Pub. L. No. 145-2016, §§ 23-27, 29, 2016 Ind. Acts 1333, 1359-64 (amending IND. CODE $\S$ 6-3.1-13 (Economic Development for a Growing Economy Tax Credit) to replace references to the IEDC's president with references to the IEDC itself).

73. See id. $\S \S 30-35,2016$ Ind. Acts at 1364-68 (amending IND. CoDE $\S 6-3.1-26$ (Hoosier Business Investment Tax Credit) to replace references to the IEDC's president with references to the IEDC itself).

74. See id. $\S \S 36-41,2016$ Ind. Acts at 1368-71 (amending IND. CoDE $\S 6-3.1-31.9$ (Hoosier Alternative Fuel Vehicle Manufacturer Tax Credit) to replace references to the IEDC's president with references to the IEDC itself). 
compliant, for requesting that the DOR assess the taxpayer an amount that cannot exceed the sum of the previously-permitted credits and any penalties and interest due on those credits. $^{75}$ The GA also modified the Individual Development Account Tax Credit to restrict that credit to qualified contributions made to individual development account funds "for which a community development corporation has received an allocation of tax credits."

The Industrial Recovery Tax Credit received some attention, too. Specifically, the GA revised the definition of "industrial recovery site" to cover land with $a \geq 100,000$ square foot vacant plant on it that either (1) exists on the date of application and was placed in service at least fifteen years before that date or (2) existed within five years of the application date and was placed in service at least fifteen years before its demolition. ${ }^{77}$ To receive a tax credit for a previously-demolished vacant plant, the taxpayer must prove that "the plant was not maintained and was removed from the [industrial recovery] site in an effort to protect the health, safety, and welfare of the community." 78 Successful taxpayers will receive a tax credit calculated using an applicable percentage that depends on the length of time between the completion of that demolition and the application date. ${ }^{79}$ Furthermore, a taxpayer who wishes to claim the credit must enter into a tax credit agreement with the IEDC. ${ }^{80}$

\section{E. Local Taxes}

After a momentous 2015 legislative session that saw the consolidation of the parallel CAGIT, COIT, and CEDIT regimes into a single local income tax that took their place on January 1, 2017, ${ }^{81}$ the GA largely limited itself to putting the finishing touches on that transition and to the local taxation of motor vehicles. ${ }^{82}$ Most significantly, the GA created a new municipal motor vehicle license excise

75. Id. $\S \S 28,34,39,2016$ Ind. Acts at 1364, 1366-67, 1370 (amending IND. CoDE $\S \S 6-3.1-$ 13-22, -26-23, and -31.9-20).

76. Pub. L. No. 50-2016, § 10, 2016 Ind. Acts 400, 405 (amending InD. CodE § 6-3.1-184.5).

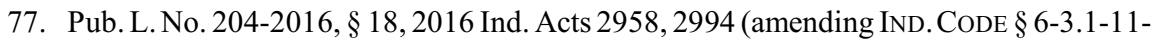
5).

78. Id. $\S 24,2016$ Ind. Acts at 2996 (amending IND. CODE $\S 6-3.1-11-19$ ).

79. Id. $\S 16,2016$ Ind. Acts at 2993-94 (amending IND. CoDE $§ 6-3.1-11-1$ ).

80. Id. $\S 25,2016$ Ind. Acts at 2996 (codified at IND. CODE $§ 6-3.1-11-19.5$ ).

81. Jegen et al., 2015, supra note 1, at 1252-55 (outlining the broad contours of the transition to the new local income taxation regime).

82. See, e.g., Pub. L. No. 197-2016, §§ 34-35, 2016 Ind. Acts 2232, 2290-91 (amending IND. CODE $\S \S 6-3.5-4-1$ and -4-1.1 to update the adopting entity definition in the County Motor Vehicle Excise Surtax to reflect the "local income tax council" relevant under the new local income tax statute in IND. CODE $\S$ 6-3.6). The GA also repealed three now-obsolete chapters: Status of Certain Property Tax Credits, Adoption of Certain Ordinances Relating to a County Adjusted Gross Income Tax or a County Option Income Tax, and Employment Tax. Id. $\S \S 31-33,2016$ Ind. Acts at 2290 (repealing IND. CODE $\S \S 6-3.5-0.7,-0.8$, and -2). 
surtax (the "License Surtax") and a municipal wheel tax (the "Wheel Tax") that parallel the existing county versions. ${ }^{83}$

The two new vehicle-related taxes may only be adopted in conjunction with each other by a municipality that contains more than 10,000 people and that uses a transportation asset management plan approved by the Indiana Department of Transportation. ${ }^{84}$ The new statutes guarantee at least a six-month delay after the new taxes are adopted before they become effective.$^{85}$ Once in place, no vehicle may be registered in the adopting municipality unless the License Surtax and Wheel Tax are paid to the Bureau of Motor Vehicles. ${ }^{86}$ The License Surtax applies to passenger vehicles, motorcycles, trucks with declared gross weight less than 11,000 pounds, and motor driven cycles, ${ }^{87}$ and may be set anywhere between $\$ 7.50$ and $\$ 25$ per year in an amount that may apply to all motor vehicles or may vary by vehicle class. ${ }^{88}$ Adjustments to the License Surtax amount owed for a given year after a mid-year acquisition, sale, or other registration change are calculated using the same rules that apply similar changes under the Motor Vehicle Excise Surtax. ${ }^{89}$ The Wheel Tax applies to buses, recreational vehicles, semitrailers, tractors, trailers, and trucks ${ }^{90}$ that are not (1) owned by the state, (2) subject to the License Surtax, or (3) a bus owned and used by a religious or nonprofit youth organization to transport people as part of its religious or youth services. ${ }^{91}$ The Wheel Tax may be set anywhere between five dollars and forty dollars per year in an amount that may apply to all motor vehicles within a given classification or may vary by weight within each vehicle class. ${ }^{92}$ Commercial vehicle owners who pay an apportioned registration to the state under the International Registration Plan may calculate the wheel tax due "by dividing in-

83. See Pub. L. No. 146-2016, §§ 11-12, 2016 Ind. Acts 1371, 1379-88 (codified at IND. CoDE $§ \S 6-3.5-10$ (Municipal Motor Vehicle License Excise Surtax) and -11 (Municipal Wheel Tax)).

84. Seeid. (codified at IND. CoDE $\S \S 6-3.5-10-2(a),-10-2(d),-10-2(e),-11-2(a),-11-2(b)$, and $-11-2(\mathrm{c}))$.

85. See id. (codified at IND. CoDE $\S \S 6-3.5-10-3$ and -11-5, each of which provides that a tax adopted during the first half of a calendar year takes effect after December 31 of that year and that one adopted during the second half of a calendar year takes effect after December 31 of the following year). Those delayed-effectiveness rules also apply to changes in the License Surtax and Wheel Tax amounts. Id. (codified at IND. CODE $§ \S 6-3.5-10-5$ and -11-7). Rescissions take effect at the end of the year in which the rescission is approved and must cover both the License Surtax and the Wheel Tax to be effective. Id. (codified at IND. CODE $\S \S 6-3.5-10-4$ and -11-6).

86. Id. (codified at IND. CoDE $\S \S 6-3.5-10-7$ and -11-10).

87. Id. § 11, 2016 Ind. Acts at 1379-83 (codified at IND. CODE § 6-3.5-10-2(c)).

88. Id. (codified at IND. CODE $§ 6-3.5-10-2$ (a) and (b)).

89. Id. $\S \S 11-12,2016$ Ind. Acts at 1379-88 (codified at IND. CoDE $\S \S 6-3.5-10-8$ and -1110).

90. Id. $\S 12,2016$ Ind. Acts at 1383-88 (codified at IND. CODE $\S 6-3.5-11-3$ ).

91. Id. (codified at IND. CoDE $\S 6-3.5-11-4)$.

92. Id. (codified at IND. CODE $\S 6-3.5-11-2(\mathrm{~d})$ ). 
state actual miles by total fleet miles generated during the preceding year. ${ }^{, 93} \mathrm{An}$ owner who sells a vehicle may claim a credit for the wheel tax paid on that vehicle against the wheel tax due on another vehicle purchased during the same year. ${ }^{94}$ All amounts collected from the License Surtax must be placed in a "municipal surtax fund" that is used to "construct, reconstruct, repair, or maintain streets and roads. ${ }^{" 95}$ Similar rules apply to the Wheel Tax revenue. ${ }^{96}$

At the county level, the GA adjusted the permissible county motor vehicle excise surtax and county wheel tax levels for counties that use a transportation asset management plan. ${ }^{97}$ Specifically, those counties may impose a motor vehicle excise surtax at a rate of up to twenty percent or a fixed amount of up to fifty dollars, ${ }^{98}$ and may impose a wheel tax of up to eighty dollars. ${ }^{99}$ These two countylevel taxes were also amended to permit the DOR or the Bureau of Motor Vehicles to impose a $\$ 0.15$ service charge on each tax collection before the collecting agency deposits the remaining funds in the appropriate fund. ${ }^{100}$

The GA's work on local income taxes largely dealt with cleaning up the new statutory system adopted in $2015,{ }^{101}$ and with adjusting the various participants' roles and responsibilities under that system. ${ }^{102}$ As usual, there were a few countyspecific taxes authorized. ${ }^{103}$ Oddly, the GA also repealed a tax benefit that it went

93. Id. (codified at IND. CODE $\S 6-3.5-11-11)$.

94. Id. (codified at IND. CODE $\S 6-3.5-11-9)$.

95. Id. (codified at IND. CODE $§ 6-3 \cdot 5-10-10$ ).

96. Id. (codified at IND. CODE $§ 6-3.5-11-14$ ).

97. Id. § 6, 2016 Ind. Acts at 1375-77 (amending IND. CODE § 6-3.5-4-2). The GA also modified the definition of a "transportation asset management plan" to include "planning for drainage systems and rights-of-way that affect transportation assets." Id. § 5, 2016 Ind. Acts at 1375 (amending IND. CODE $\S 6-3.5-4-1$ ).

98. Id. § 6, 2016 Ind. Acts at 1375-77 (amending IND. CODE § 6-3.5-4-2). Counties that do not use a transportation asset management plan are limited to ten percent and twenty dollars. IND. CODE $\S 6-3.5-4-2$.

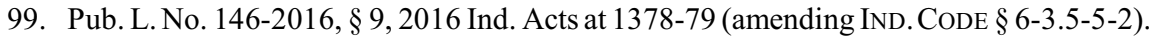
Counties that do not use a transportation asset management plan are limited to forty dollars. IND. CODE $§ 6-3.5-5-2$.

100. Pub. L. No. 198-2016, §§ 23, 25, 2016 Ind. Acts 2399, 2417-18 (amending Ind. CodE $\S \S 6-3.5-4-15.5$ and -5-9).

101. See, e.g., Pub. L. No. 197-2016, § 69, 2016 Ind. Acts 2232, 2318-19 (amending IND. CODE $§ 6-3.6-11-1$ to correct a typographical error and to remove a reference to a section that was repealed in 2015).

102. See, e.g., Pub. L. No. 126-2016, §§ 1-2, 2016 Ind. Acts 1222, 1222-24 (amending IND. CODE $\S \S 6-3.6-9-1$ and -15 to empower each county's budget agency to maintain that county's trust account and to require a trust account distribution to the county whenever the trust account's balance exceeds fifteen percent of the county's certified distributions for the relevant determination year).

103. See, e.g., Pub. L. No. 197-2016, § 62, 2016 Ind. Acts at 2311-13 (codified at IND. CodE $\S 6-3.6-7-21.5$ to permit Tipton County to impose an additional income tax rate for a list of specific purposes). 
to the trouble of carrying over from the outgoing CAGIT/COIT/CEDIT system just last year ${ }^{104}$ - the tax credit for certain elderly and disabled individuals. ${ }^{105}$ The most significant statewide adjustment was the authorization of a local income tax rate to pay for public safety emergency assistance points ("PSAPs") that are part of the statewide 911 system. ${ }^{106}$ A county's local income tax council may impose a tax rate of up to $0.1 \%$ to pay for a PSAP in the county, provided the county has not already allocated expenditure rate revenue of at least that amount to pay for the PSAP. ${ }^{107}$ The revenue from this PSAP tax rate must be segregated and used solely for the PSAP. ${ }^{108}$ The GA also added a PSAP to the list of items that are considered for "public safety" and may be funded from revenue raised by the expenditure rate. ${ }^{109}$ In addition, the GA required allocation of public safety expenditure rate tax revenue to the PSAP before any amounts may be allocated to other public safety purposes. ${ }^{110}$

\section{F. Death Taxes}

As everyone reading this article undoubtedly knows, in 2013 the GA repealed Indiana's inheritance, estate, and generation-skipping taxes for deaths occurring after December 31, 2012. ${ }^{111}$ In 2016, the GA shifted responsibility for handling many inheritance tax matters from the probate courts and county assessors to the DOR. ${ }^{112}$ The DOR is now responsible for receiving inheritance tax returns and "no inheritance tax is due" petitions filed after March 31, 2016. ${ }^{113}$ The DOR is also responsible for appraising future, contingent, defeasible, and life interests in property shown on those returns, ${ }^{114}$ and for determining the final inheritance tax liability of all decedents who have not received such an order establishing that

104. See Jegen et al., 2015, supra note 1, at 1255 (reporting the adoption of IND. CoDE § 6-3.6$8-8)$.

105. Pub. L. No. 197-2016, § 65, 2016 Ind. Acts at 2314-15 (repealing IND. CodE $§ 6-3.6-8-8$ ).

106. Pub. L. No. 180-2016, § 16, 2016 Ind. Acts 1897, 1909 (codified at IND. CoDE § 6-3.6-62.5).

107. Id.

108. Id.

109. Pub. L. No. 197-2016, § 44, 2016 Ind. Acts at 2295-96 (amending IND. CoDE § 6-3.6-214).

110. Id. § 71, 2016 Ind. Acts at 2320-21 (amending IND. CODE § 6-3.6-11-4).

111. See Jegen et al., 2013, supra note 1, at 1174.

112. See Pub. L. No. 190-2016, §§ 2-4, 10, 2016 Ind. Acts 2150-55 (amending IND. CodE $\S \S$ 6-4.1-4-1, -4-2, -4-6, and -5-7).

113. Id. (requiring the filing of those returns and petitions with the DOR, and empowering the DOR to grant filing extensions and impose late filing penalties for them).

114. Id. $\S \S 15-18,2016$ Ind. Acts at 2157-59 (amending IND. CODE §§ 6-4.1-6-1, -2, -4, and -6). At the same time, the GA cut off the probate courts' jurisdiction over the original determination of inheritance tax due for returns filed after March 31, 2016. Id. § 30, 2016 Ind. Acts at 2165 (amending IND. CODE $\S 6-4.1-12-2$ ). 
liability prior to April 1, 2016. ${ }^{115}$ The resulting tax payments are due to the DOR, ${ }^{116}$ and the DOR has the power to adjust late payment interest rates on delinquent payments when an unavoidable delay prevents determination of the proper amount due. ${ }^{117}$ Taxpayers who wish to challenge the DOR's property appraisal or its inheritance tax liability determination may appeal to the appropriate probate court. ${ }^{118}$ The probate court's decision may be appealed to the Tax Court. ${ }^{119}$

\section{G. Excise Taxes and Other Miscellaneous Taxes}

For excise taxes, 2016 was fairly uneventful. In addition to making some minor changes to motor vehicle and fuel excises taxes, the GA (1) tweaked the cigarette tax by repealing its application to cigarette papers, wrappers, and tubes ${ }^{120}$ and by increasing the discounted stamp price for distributers to $\$ 0.013$ per individual cigarette package; ${ }^{121}$ (2) clarified that a county treasurer's rights and powers extend to refunding the county innkeeper's tax; ${ }^{122}$ (3) readjusted the Henry County Food and Beverage $\operatorname{Tax}^{123}$ and the Allen County Supplemental Food and Beverage Tax; ${ }^{124}$ (4) clarified that employer-deposited amounts that are placed in an Employee Medical Care Savings Account Plan after December 31, 2015 , and are not exempt from Indiana or U.S. income taxation when contributed, may be withdrawn without being subject to Indiana's adjusted gross income $\operatorname{tax} ;{ }^{125}$ and (5) urged the legislative services agency to study "the taxation of paid

115. Id. $\S \S 11,13,2016$ Ind. Acts at 2154-57 (amending IND. CoDE $\S \S 6-4.1-5-8$ and -10). At the same time, the GA cut off the county assessors' authority to appraise property interests for inheritance tax purposes returns filed after March 31, 2016. Id. § 29, 2016 Ind. Acts at 2164-65 (amending IND. CODE $\S 6-4.1-12-1$ ).

116. Id. $\S 25,2016$ Ind. Acts at 2162 (amending IND. CODE $\S 6-4.1-9-5$ ).

117. Id. $\S 24,2016$ Ind. Acts at 2161-62 (amending IND. CODE § 6-4.1-9-1).

118. Id. $\S \S 19-20,2016$ Ind. Acts at 2159-60 (amending IND. CoDE $\S \S 6-4.1-7-1$ and -2). This shift in responsibility required some procedural clarification, too. See, e.g., id. §22, 2016 Ind. Acts at 2160-61 (amending IND. CODE $\S 6-4.1-7-4$ to require a probate court that is redetermining the inheritance tax due to follow many of the procedures that it used for original inheritance tax determinations prior to April 1, 2016, or to follow the procedures used by the DOR when determining original inheritance tax liability after March 31, 2016).

119. Id. § 23, 2016 Ind. Acts at 2161 (codified at IND. CoDE $\S 6-4.1-7-6.5$ ).

120. Pub. L. No. 191-2016, $\S ~ 1-5,2016$ Ind. Acts 2186, 2186-88 (amending IND. CodE $\S \S$ $6-7-1-2,-3 .-9,-12$, and -14$)$.

121. Id. $\S 6,2016$ Ind. Acts at 2188-89 (amending IND. CODE $\S 6-7-1-17$ ).

122. Pub. L. No. 181-2016, § 31, 2016 Ind. Acts 1924, 1970 (amending IND. CoDE § 6-9-293).

123. Pub. L. No. 194-2016, §§ 1-3, 2016 Ind. Acts 2221, 2221-24 (amending IND. CodE $\S 6-9-$ 25-9.5 and adding IND. CoDE $\S \S 6-9-25-1.5$ and -25-15).

124. Id. $\S 4,2016$ Ind. Acts at 2224-25 (codified at IND. CoDE $\S 6-9-33-7.5$ ).

125. Pub. L. No. 122-2016, § 8, 2016 Ind. Acts 1187, 1211 (amending InD. CoDE $\S 6-8-11$ $11.5)$. 
fantasy sports." 126

In the area of motor vehicle and fuel excise taxes, the GA's most significant acts were to exclude the inventory of licensed dealers from the motor vehicle excise tax, beginning on June $30,2017,{ }^{127}$ and to authorize refunds of gasoline tax paid on gasoline used to create racing fuel that is predominately ethanol (i.e., greater than eighty-nine percent ethanol), will not be blended into a fuel that can be used in vehicles on Indiana public highways, and will be resold to an out-ofstate purchaser. ${ }^{128}$ The GA also exempted "[s]pecial machinery (as defined in IC 9-13-2-170.3)" from the excise tax on recreational vehicles and truck campers, ${ }^{129}$ the commercial vehicle excise tax,${ }^{130}$ and the motor vehicle excise tax. ${ }^{131}$ The latter tax no longer applies to "[b]uses (as defined in IC 9-13-2-17)." "132 In addition, the GA dealt with a handful of administrative matters, such as permitting the Bureau of Motor Vehicles to use full-service and partial-service providers to administer and collect the motor vehicle excise tax,${ }^{133}$ the excise tax on recreational vehicles and truck campers, ${ }^{134}$ and the boat tax. ${ }^{135}$

\section{H. Tax Administration Matters}

The GA largely left the tax administration area alone in 2016. Other than updating the "[1]isted taxes" definition to reflect changes made elsewhere, ${ }^{136}$ the GA added the "military family relief fund" to the list of funds that taxpayers may designate to receive a portion of their individual income tax refunds. ${ }^{137}$ It also extended the time that a taxpayer has to pay the tax due in a demand notice for payment of tax from ten to twenty days after the notice's mailing date. ${ }^{138}$ Finally, the GA adjusted the allocation of funds collected by the DOR after June 30, 2015

126. Pub. L. No. 212-2016, $\S 5,2016$ Ind. Acts 3089, 3098. This study is part of the GA's decision to regulate paid fantasy sports. See id. § 2, 2016 Ind. Acts at 3089-97 (codified at IND. CODE § 4-33-24 (Paid Fantasy Sports)).

127. Pub. L. No. 174-2016, § 2, 2016 Ind. Acts 1781, 1781-83 (amending IND. CodE $§ 6-6-5-$ $1)$.

128. Pub. L. No. 204-2016, § 27, 2016 Ind. Acts 2958, 2998 (amending InD. CoDE § 6-6-1.1903).

129. Pub. L. No. 198-2016, § 38, 2016 Ind. Acts 2399, 2433-34 (amending IND. CodE § 6-6$5.1-1)$.

130. Id. $\S 46,2016$ Ind. Acts at 2445-46 (amending IND. CODE $\S 6-6-5.5-2$ ).

131. Id. $\S 31,2016$ Ind. Acts at 2423-25 (amending IND. CODE $§ 6-6-5-1$ ).

132. $I d$.

133. Id. $\S 35,2016$ Ind. Acts at 2431-33 (amending IND. CODE § 6-6-5-9).

134. Id. $\S 42,2016$ Ind. Acts at 2441-43 (amending IND. CODE § 6-6-5.1-21).

135. Id. $\S 54,2016$ Ind. Acts at 2451-52 (amending IND. CoDE $\S 6-6-11-20$ ).

136. Pub. L. No. 197-2016, § 74, 2016 Ind. Acts 2232, 2325 (amending Ind. CodE § 6-8.1-1$1)$.

137. Pub. L. No. 99-2016, § 1, 2016 Ind. Acts 957, 957-58 (amending IND. CoDE $§ 6-8.1-9-4$ ).

138. Pub. L. No. 181-2016, $\S 29,2016$ Ind. Acts 1924, 1964-68 (amending IND. CoDE $§ 6-8.1-$ $8-2)$. 
under its tax amnesty programs to reflect more closely the allocations of the taxes that make up the amnesty payments. ${ }^{139}$

\section{Indiana TAX Court Decisions}

The Tax Court rendered a variety of opinions from January 1, 2016 to December 31, 2016. ${ }^{140}$ Specifically, the Tax Court issued twenty-two published opinions: nine concerned the Indiana real property tax, five concerned the Indiana sales and use tax, three concerned Indiana business tax, four concerned Indiana individual income tax, and one concerned Indiana inheritance tax. ${ }^{141}$ The Tax Court also issued two unpublished opinions: one concerned Indiana business tax and the other concerned Indiana individual income tax. ${ }^{142}$ A summary of each opinion and decision appears below.

\section{A. Real Property Tax}

1. DeKalb County Assessor v. Chavez. ${ }^{143}$-Paul and Joan Chavez owned 5.18 acres of property in Auburn, Indiana, which the Assessor classified as one acre of residential, 2.72 wooded acres as excess residential, .68 acres as a legal ditch, and .78 acres as a public road. ${ }^{144}$ This resulted in a total assessed value of $\$ 44,200 .{ }^{145}$ The Chavezes first appealed to the DeKalb County PTABOA, which reduced the assessment to $\$ 32,800 .{ }^{146}$ The Chavezes then appealed to the Indiana Board. ${ }^{147}$ At the Indiana Board hearing, the Chavezes argued the 2.72 acres of excess residential property should be classified as agricultural because they purchased the woods with the intent to grow and harvest the trees. ${ }^{148}$ The Indiana Board found the Assessor had erred and reclassified the 2.72 acres as agricultural. ${ }^{149}$ The Assessor appealed to the Indiana Tax Court.

On appeal, the Assessor argued the Chavezes' land was not devoted to an agricultural use because they "did not have any formal plans for the harvesting of any of the trees." ${ }^{150}$ The Tax Court disagreed, explaining a timber management plan was just one factor, among others, used to determine whether land is devoted

139. Pub. L. No. 146-2016, § 13, 2016 Ind. Acts 1371, 1388-91 (amending IND. CoDE $§ 6-8.1-$ 3-25).

140. See Indiana Appellate Opinions Archive- Tax Court, IN.Gov, http://www.in.gov/ judiciary/opinions/archtax.html [https://perma.cc/2Y2M-SNJU] (last visited May 18, 2017).

141. Id.

142. $I d$.

143. 48 N.E.3d 928 (Ind. T.C. 2016).

144. Id. at 929 .

145. Id.

146. Id.

147. $I d$.

148. Id.

149. Id.

150. Id. at 930 (internal quotations omitted). 
to that agricultural use. ${ }^{151}$ The Assessor further argued that because the Chavezes never harvested any timber from the property, the land could not have been devoted to that agricultural use. Again, the Tax Court explained that timber harvests are merely one of the factors considered. ${ }^{152}$

The Assessor next argued the Indiana Board gave too much weight to the Chavezes' intent at the time of the purchase, which created an "unworkable standard" that placed an unmanageable burden on assessors. ${ }^{153}$ The Tax Court explained the Assessor's remedy for that grievance lies with the legislature, and not the Tax Court. ${ }^{154}$ Finally, the Assessor argued the Indiana Board's decision was not supported by substantial or reliable evidence because the Indiana Board relied "solely on the Chavezes' subjective intent to harvest the trees at the time of purchase." 155 The Tax Court found the Indiana Board indeed analyzed the various factors when it determined the 2.72 acres were devoted to an agricultural use. ${ }^{156}$ Furthermore, the Tax Court found "the record contains more than a scintilla of supporting evidence." ${ }^{157}$ As such, the Tax Court affirmed the Indiana Board's reclassification of the Chavezes' 2.72 acres to agricultural. ${ }^{158}$

2. Marion County Assessor v. Simon DeBartolo Group, LP. ${ }^{159}$ - In 2006 and 2007, Simon ${ }^{160}$ owned the Lafayette Square Mall (the "Mall"), which they later sold to Ashkenazy Acquisition Corporation, in December of 2007, for $\$ 18,000,000{ }^{161}$ "At the time of that sale, Simon had already initiated an administrative appeal challenging the Mall's 2006 assessed value of $\$ 56,341,000$." $^{\prime 162}$ While that appeal was pending with the Marion County PTABOA, Simon initiated another administrative appeal challenging the Mall's 2007 assessment. ${ }^{163}$ The PTABOA reduced the Mall's 2006 assessment to $\$ 28,000,100$ and the 2007 assessment to $\$ 20,000,000 .{ }^{164}$ Simon appealed to the Indiana Board.

At the Indiana Board hearing, Simon presented testimonial evidence demonstrating that it made a call for offers amongst potential buyers in the fall

151. Id. at 930-31.

152. Id. at 931 .

153. Id.

154. Id.

155. Id.

156. $I d$.

157. Id.

158. Id. at 932 .

159. 52 N.E.3d 65 (Ind. T.C. 2016).

160. Id. at 66 ("[T] he Mall was owned by Simon DeBartolo Group, LP; DeBartolo Realty Partnership, LP; and SPG Lafayette Square, LLC; all three were a part of the Simon Property Group (collectively, 'Simon').”).

161. Id.

162. Id.

163. Id. The 2007 assessed value was not provided in the certified administrative record.

164. Id. 
of 2007. ${ }^{165}$ On December 27, 2007, Simon closed on the Mall's sale to Ashkenazy. ${ }^{166}$ Further, Simon presented an analysis prepared by Sara Coers, a certified appraiser. ${ }^{167}$ Coers verified the terms of the sale and concluded the sale was an arm's-length transaction. Coers also provided trending factors, which Simons used to determine the Mall's 2006 assessment should have been $\$ 15,281,398$ and the 2007 assessment should have been $\$ 16,849,758 .^{168}$ The Assessor responded by challenging aspects of Simon's evidence. ${ }^{169}$ Specifically, the Assessor's deputy claimed that the sale of the mall might not have been an arm's-length transaction, the Mall was worth more prior to the sale because the Mall's performance declined gradually over time, the trending factors were not properly calculated, and the Mall's sales price could not reflect its 2006 and 2007 market value-in-use because Ashkenazy was not using the Mall in the same manner as Simon. ${ }^{170}$ The Assessor asserted that an income approach was more proper and submitted a valuation of $\$ 34,600,000$ for 2006 and $\$ 30,800,000$ for 2007. ${ }^{171}$

On October 3, 2012, the Indiana Board found the Mall's December 2007 sales price of $\$ 18,000,000$ was the best indication of its market value as of that date. ${ }^{172}$ Therefore, the Indiana Board held Simon's evidence established a prima facie case that the Mall's assessment should have been $\$ 15,281,398$ in 2006 and $\$ 16,849,758$ in $2007 .{ }^{173}$ The Indiana Board further found the Assessor's evidence had failed to rebut Simon's prima facie showing because, in part, the Assessor's own evidence had shown the Mall's performance was stable, the deputy erred in relying on the Mall's actual income and expenses, and the deputy failed to provide any support for the capitalization rates used in her income approach valuation. ${ }^{174}$ The Assessor appealed to the Indiana Tax Court.

On appeal, the Assessor argued the Indiana Board's final determination was not in accordance with the law and constituted an abuse of discretion because it was not supported by substantial or reliable evidence. ${ }^{175}$ The Assessor submitted a two-sentence argument in support of the claim that the final determination was not in accordance with the law. ${ }^{176}$ The Tax Court stated the argument "warrant[ed] no attention from the Court." 177

The Assessor further contended the Indiana Board erroneously relied upon

165. Id. at 66-67.

166. Id. at 67 .

167. Id.

168. Id.

169. $I d$.

170. $I d$.

171. Id. at 68 .

172. Id.

173. Id.

174. Id.

175. Id. at 68-69.

176. Id. at 69 .

177. Id. 
the December 2007 sales price to support a reduction in the prior assessments. ${ }^{178}$ Specifically, the Assessor argued the Mall's 2007 sales price was too remote from the valuation dates to be considered relevant and that Simon failed to prove the sale represented the market value. ${ }^{179}$ To the first point, the Tax Court explained that "this Court has long recognized that in assessment challenges, taxpayers can present evidence of present-day property values as long as they attempt to relate that evidence to the appropriate valuation and assessment dates." ${ }^{180}$ In regard to the second part of the Assessor's argument, the Tax Court found Simon made a prima facie case that the 2007 sales price was representative of market because the sale met the conditions outlined by Indiana's Property Assessment Manual. ${ }^{181}$ At that point, the Assessor had the burden of rebutting Simon's prima facie case, which the Assessor failed to do. ${ }^{182}$ The Assessor also presented a series of arguments that the Indiana Board improperly relied upon the Coers Analysis to support a reduction for the 2006 and 2007 assessments. ${ }^{183}$ First, the Assessor contended his deputy presented evidence that showed a decline in value between January 2005 and December 2007, which relied in part on the premise that some parts of the Mall were not included in the sale. ${ }^{184}$ However, the Tax Court explained the deputy did not identify, or provide, any evidence substantiating the Sears store, Ayres store, or tire store were not included in the Mall's sale. ${ }^{185}$ To the contrary, the Tax Court determined the administrative record clearly indicated the Ayres and tire store were included in the Mall's sale. ${ }^{186}$

Second, the Assessor argued the Coers Analysis should have been rejected because the trending factors were not appropriately developed. ${ }^{187}$ The Tax Court rejected this argument and stated that the Assessor failed to provide an authoritative source explaining how trending factors should be calculated. ${ }^{188}$ Finally, the Assessor contended that because Coers would not render a value for the Mall, Simon's attorney was the only person to contend the Mall's sales price adjusted by the trending factors was its market value-in-use. ${ }^{189}$ The Assessor argued Simon's attorney was not sworn in as a witness, did not attest to his computations conforming to USPAP, and "he was acting in the capacity of an advocate." ${ }^{190}$ However, the Tax Court explained Simon's attorney presented, as

178. Id.

179. Id.

180. Id. at 70. See, e.g., O’Donnell v. Dep't of Local Gov't Fin., 854 N.E.2d 90, 95 (Ind. T.C. 2006).

181. Simon, 52 N.E.3d at 71.

182. Id.

183. $I d$.

184. Id. at 71-72.

185. Id. at 72 .

186. Id.

187. Id.

188. Id.

189. Id. at 72-73.

190. Id. 
demonstrative evidence, a piece of paper that performed the math. ${ }^{191}$ The Tax Court was not persuaded by the Assessor's argument that "the actions of Simon's attorney rendered an opinion of value subject to USPAP or that he needed to be sworn in as a witness." ${ }^{192}$ Further, the Tax Court noted "the Assessor's counsel conceded that if the trending factors were reliable, then 'anybody'-including Simon's attorney-could have done the math." ${ }^{\prime 193}$ Therefore, the Tax Court found the Assessor did not establish that the trending factors were improperly developed. ${ }^{194}$ As such, the Tax Court found the Assessor failed to rebut the prima facie case and affirmed the final determination of the Indiana Board. ${ }^{195}$

3. Jones v. Jefferson County Assessor. ${ }^{196}$ - Larry and Sharon Jones own a single-family home on approximately 100 acres of farmland in Hanover, Indiana. ${ }^{197}$ The property was assessed at $\$ 501,400$ in 2008 and $\$ 505,100$ in $2009 .{ }^{198}$ The Joneses contacted the Jefferson County Assessor to explain the assessments were in error because the residence was not $100 \%$ complete as of the assessment dates. ${ }^{199}$ The Assessor inspected the exterior of the property and determined the residence appeared complete and occupied. ${ }^{200}$ The PTABOA later denied the Joneses' appeal. ${ }^{201}$ Subsequently, the Joneses appealed to the Indiana Board.

At the Indiana Board hearing, the Joneses did not contest the land value, but argued the residence should have been assessed at $\$ 0$ for the years at issue. ${ }^{202}$ To support their claim, the Joneses presented a document prepared by the former Trustee/Assessor of Hanover Township, which explained that litigation between the Joneses and the contractor resulted in the house being incomplete and uninhabitable. ${ }^{203}$ Further, the Trustee/Assessor explained the residence should not have been assessed because it was uninhabitable. ${ }^{204}$ The Assessor responded by arguing the Trustee/Assessor's document lacked probative value because it was not notarized and contained unattributed handwritten alterations. ${ }^{205}$ Moreover, the Assessor argued it was reasonable to believe the Joneses lived at the residence because they received a homestead deduction in 2008. ${ }^{206}$ The Indiana Board

191. Id. at 73 .

192. Id. at 73 .

193. Id.

194. Id.

195. Id.

196. 51 N.E.3d 461 (Ind. T.C. 2016).

197. Id.

198. Id. at 462.

199. Id.

200. Id.

201. Id.

202. Id.

203. Id.

204. Id.

205. Id.

206. Id. 
issued a final determination finding the Joneses' residence was assessed as if it were $100 \%$ complete, although it was not. ${ }^{207}$ Nonetheless, the Indiana Board found the assessment must stand because the Trustee/Assessor's document was unreliable and did not provide sufficient support for the requested $\$ 0$ valuation. ${ }^{208}$ The Joneses appealed to the Indiana Tax Court. ${ }^{209}$

On appeal, the Joneses argued their residence was clearly incomplete and thus ineligible for assessment in 2008 and $2009 .^{210}$ The Tax Court was not persuaded by this argument. The Tax Court pointed to Indiana Code section 6-1.1-2-1, which provides "all tangible property which is within the jurisdiction of this state on the assessment date of a year is subject to assessment and taxation for that year." 211 The Tax Court explained "the Assessor was required to determine the true tax value." ${ }^{212}$ Moreover, the Tax Court explained that when an assessor has assessed real property pursuant to the guidelines, as is the case here, the assessment is presumed accurate. ${ }^{213}$ However, the taxpayer may rebut that presumption with other market-based evidence that demonstrates the assessment does not reflect the market value-in-use. ${ }^{214}$ The Tax Court found the Joneses did not provide the Indiana Board with any market-based evidence of their property's market value-in-use. ${ }^{215}$ Therefore, the Tax Court affirmed the Indiana Board. ${ }^{216}$

4. Gillette v. Brown County Assessor. ${ }^{217}$ - Gillette owns a rental property in Nineveh, Indiana, which was assessed at $\$ 636,500$ for the 2009 tax year. ${ }^{218}$ Gillette appealed, first to the PTABOA, then to the Indiana Board. ${ }^{219}$ The Assessor stated that she could not make a prima facie case and requested that the Indiana Board reinstate Gillette's 2008 assessment of $\$ 592,000{ }^{220}$ However, Gillette argued the property was only worth $\$ 440,000 .{ }^{221}$ In support of her argument, Gillette stated that the property was worth less because it abutted the road instead of the lake, her insurance liability limits to rebuild the home were much less than the assessed value, and appraisals valued her home at $\$ 260,000$ in 1998 and $\$ 482,000$ in $2006 .{ }^{222}$ Moreover, Gillette contended she could not sell the property for more than $\$ 600,000$ and could not rent it for $\$ 2,500$ per

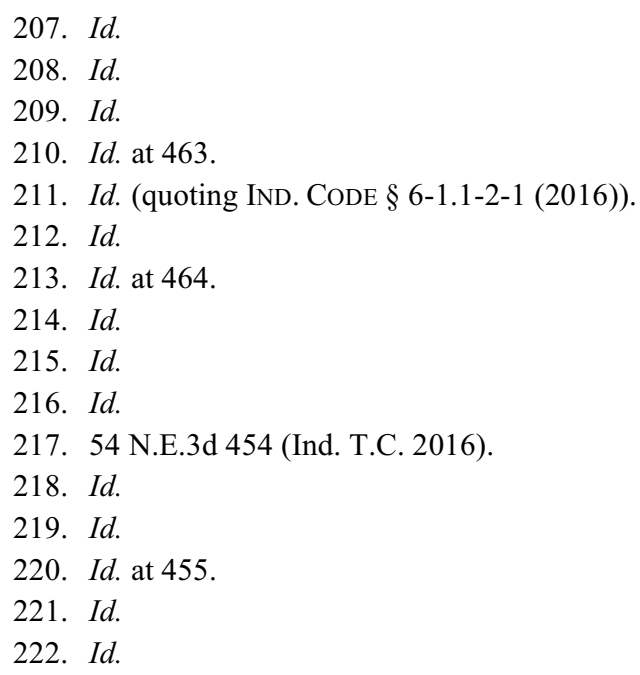


month - which meant it had a rental value of less than $\$ 250,000{ }^{223}$ The Indiana Board found Gillette failed to rebut the prima facie case for an assessed value below $\$ 592,000$ because Gillette "did not provide substantial, probative evidence to support her claim." 224 Gillette appealed to the Tax Court. ${ }^{225}$

On appeal, Gillette claimed the Indiana Board erred by using a cost approach valuation, rather than an income approach. ${ }^{226}$ In the alternative, Gillette argued the Indiana Board erred in rejecting her evidentiary presentation. ${ }^{227}$ The Tax Court disagreed and stated that Gillette "attack[ed] merely the methodology used to determine the 2008 assessed value and $\mathrm{d}[\mathrm{id}]$ not address the key issue-whether $\$ 592,000$ was a reasonable reflection of the property's market value-in-use. ${ }^{, 22}$ As such, the Court found no basis to reverse the Indiana Board on that issue. ${ }^{22}$ Gillette also contended that she presented market-based evidence-her rental insurance policy declarations, a 1998 appraisal, and a 2006 appraisal - that established the property's value was $\$ 440,000$ for the 2009 tax year. ${ }^{230}$ The Tax Court did not find this evidence probative and explained Gillette had failed to relate her evidence to the valuation date. ${ }^{231}$ Therefore, the Tax Court affirmed the Indiana Board's final determination. ${ }^{232}$

5. Monroe County Assessor v. SCP 2007-C-26-002, LLC. ${ }^{233}$ - The subject property in this case is a CVS store in Bloomington, Indiana. ${ }^{234}$ The property was assessed between $\$ 3,817,000$ and $\$ 3,933,900$ for the 2009 through 2013 assessments (the years at issue). ${ }^{235} \mathrm{CVS}$ filed appeals with the Monroe County PTABOA, which affirmed the assessments. ${ }^{236}$ Subsequently, CVS filed appeals with the Indiana Board, which consolidated the appeals and conducted a hearing in August of $2014 .{ }^{237}$ At the hearing, both parties presented appraisal reports. ${ }^{238}$ Although the appraisal reports arrived at substantially different values, they both used the sales comparison, income, and cost approaches to determining the value of the subject property. ${ }^{239}$ In addition, the Assessor presented a critique of CVS's

223. $I d$.

224. Id. (internal quotations omitted).

225. $I d$.

226. Id.

227. Id. at 456 .

228. Id.

229. $I d$.

230. Id. at 456-57.

231. Id. at 457.

232. Id.

233. 62 N.E.3d 478 (Ind. T.C. 2016).

234. Id. at 479 .

235. Id.

236. $I d$.

237. Id.

238. Id.

239. Id. 
appraisal, which was performed by a third certified appraiser. ${ }^{240}$ The Assessor's review claimed the CVS appraisal report did not properly measure market valuein-use because it used data from properties that had general retail uses rather than data from properties that were being used "for a successful ongoing CVS operation." 241

The Indiana Board disagreed and cited to a Tax Court opinion that explained "a property's market value-in-use should be measured against properties with a comparable use (e.g., general retail or light manufacturing) as opposed to properties with identical users. ${ }^{\text {242 }}$ The Indiana Board ultimately found the CVS appraisal report to be more credible; therefore, the Indiana Board reduced the property's assessments to between $\$ 2,110,000$ and $\$ 2,620,000$, for the years at issue. ${ }^{243}$ The Assessor appealed to the Tax Court. ${ }^{24}$

On appeal, the Assessor argued the Indiana Board's final determination was contrary to law and was arbitrary and capricious. ${ }^{245}$ The Assessor asserted the Indiana Board's reliance on Meijer, ${ }^{246}$ Trimas Fasteners, ${ }^{247}$ and Millennium ${ }^{248}$ cases was misplaced because those cases were wrongly decided by the Tax Court. ${ }^{249}$ The Tax Court explained the Assessor's reasoning was incorrect and the Tax Court has rejected the same argument on multiple previous occasions. ${ }^{250}$ Further, the Tax Court stated that "its previous cases correctly explain the market value-in-use standard and that the Court is not the proper arena to change a law." ${ }^{251}$ The Assessor also argued the Indiana Board's final determination was "muddle, inconsistent... [and] doesn't make sense."252 The Tax Court found the Assessor was asking the Tax Court to revisit the claim that the market value-inuse was interpreted incorrectly and to establish bright-line rules for comparable properties. ${ }^{253}$ The Tax Court cited to opinions establishing that the Tax Court did not need to address either of these claims. ${ }^{254}$ As such, the Tax Court affirmed the Indiana Board's final determination. ${ }^{255}$

6. Hamilton Square Investments, LLC v. Hamilton County

240. Id.

241. Id. (internal quotations omitted).

242. Id. at 479-80.

243. Id. at 480 .

244. Id.

245. Id. at $480-81$.

246. 979 N.E.2d 192 (Ind. T.C. 2012).

247. 926 N.E.2d 1134 (Ind. T.C. 2010).

248. 923 N.E.2d 496 (Ind. T.C. 2010).

249. Monroe Cty., 62 N.E.3d at 481.

250. Id.

251. Id.

252. Id. (internal quotations omitted).

253. Id. at 482 .

254. See, e.g., Howard Cty. Assessor v. Kohl's Ind. LP, 57 N.E.3d 913 (Ind. T.C. 2016).

255. Monroe Cty., 62 N.E.3d at 482. 
Assessor. ${ }^{256}$ - Hamilton Square owns a 200 -unit apartment complex in Westfield, Indiana, which was assessed at $\$ 5,030,900$ for the 2012 tax year. ${ }^{257}$ The Assessor classified approximately seventy percent of the property as residential and the remaining as nonresidential. ${ }^{258}$ In accordance with Indiana Code section 6-1.120.6-7.5, the residential portion received a two percent tax cap credit and the nonresidential portion received a three percent tax cap credit. ${ }^{259}$ Hamilton Square filed a Notice of Review with the PTABOA because it believed the Assessor had misclassified the property. ${ }^{260}$ Subsequently, because the PTABOA took no action, Hamilton Square filed a Petition for Review with the Indiana Board. ${ }^{261}$ The parties agreed the matter could be resolved through summary judgment. ${ }^{262}$ In its brief, Hamilton Square argued the Assessor misclassified the property by limiting "common areas" to areas shared in the actual dwelling units-instead of the areas that are shared by the residents. ${ }^{263}$ In contrast, the Assessor argued her classification and allocation of tax cap credits comported with the relevant statutes. ${ }^{264}$ The Indiana Board agreed with the Assessor and found "common areas" were limited to the footprint of the apartment building. ${ }^{265}$ When the Indiana Board declined to rehear the matter, Hamilton Square filed an appeal with the Indiana Tax Court. ${ }^{266}$

On appeal, Hamilton Square argued the Indiana Board erred when it interpreted "common areas" to mean "solely the land and improvements within the footprint of a multi-unit apartment building (e.g., hallways and stairways)."267 Hamilton Square asserted that common areas also included land and improvements outside of the apartment building's footprint, such as paving, pools, remaining land, and clubhouses. ${ }^{268}$ The Assessor argued the statute unambiguously excluded standalone structures and their supporting land from the "common areas" meaning. ${ }^{269}$ The Tax Court explained the statute is subject to judicial construction because it is ambiguous. ${ }^{270}$ The Tax Court determined that "“common area' must be understood to include land and improvements that are both attached to, and separated from, a multi-unit apartment building so long as

256. 60 N.E.3d 313 (Ind. T.C. 2016), trans. denied, No. 49T10-1505-TA-18, 2017 WL 1900323 (Ind. May 2, 2017).

257. Id. at 315 .

258. Id.

259. Id.

260. $I d$.

261. Id.

262. Id.

263. Id.

264. Id.

265. Id. at 315-16.

266. Id. at 316.

267. Id.

268. Id. at 316-17.

269. Id. at 317.

270. Id. 
the area is available for the shared use of tenants. ${ }^{271}$ Further, the Tax Court explained the Assessor had misconstrued the statute and "the actual structure and language of the Residential Property Statute does not limit common areas to an apartment building's footprint as the Assessor has argued." 272 Accordingly, the Tax Court reversed the Indiana Board's final determination. ${ }^{273}$

7. Howard County Assessor v. Kohl's Indiana LP. ${ }^{274}$-Kohl's owned and occupied a retail store in Kokomo, Indiana, which it constructed in $2003 .{ }^{275}$ The property was assessed at $\$ 5,984,000, \$ 5,685,300$, and $\$ 5,906,300$ for the tax years 2010, 2011, and 2012, respectively. ${ }^{276}$ Kohl's appealed to the Howard County PTABOA, which affirmed the assessments. ${ }^{277}$ Kohl's appealed to the Indiana Board. ${ }^{278}$ Both parties presented summary appraisal reports that valued the property for each year at issue. ${ }^{279}$ The Kohl's appraisal used the sales comparison, the income, and the cost approach to value the property-resulting in a market value-in-use amount of $\$ 3,690,000, \$ 3,820,000$, and $\$ 3,680,000$ for 2010,2011 , and 2012, respectively. ${ }^{280}$ The Assessor's appraisal employed the cost approach and sales comparison approach to determine a market value-in-use of $\$ 4,920,000$ for $2010, \$ 4,770,000$ for 2011 , and $\$ 4,810,000$ for $2012 .^{281}$ The Indiana Board noted the parties had differing interpretations of the market valuein-use standard ${ }^{282}$ Further, the Indiana Board explained "the Kohl's appraisal relied on data from the fee simple sales of nine Midwestern 'big box' retail stores." ${ }^{283}$ Kohl's believed the vacant comparable properties reflected the value of only the real property. ${ }^{284}$ However, the Assessor's appraiser believed that vacant stores were not appropriate because they "do not have any utility to either the original owner or another owner/user 'in the same retail tier' and . . . the subject property was a special purpose property because Kohl's built it to its own specifications. ${ }^{285}$ The Assessor's appraiser therefore determined Kohl's had calculated the property's market value instead of its market value-in-use. ${ }^{286}$ The Assessor's appraisal relied on "data from sales of big boxes with leases to either

271. Id.

272. Id. at 318 .

273. $I d$.

274. 57 N.E.3d 913 (Ind. T.C. 2016), trans. denied, No. 49T10-1502-TA-4, 2017 WL 1655319 (Ind. Apr. 27, 2017).

275. Id. at 914 .

276. $I d$.

277. Id.

278. $I d$.

279. Id.

280. $I d$.

281. Id. at $914-15$.

282. Id. at 915.

283. Id.

284. Id.

285. Id.

286. Id. 
Kohl's or another 'first generation' user."287 Ultimately, the Indiana Board found Kohl's appraisal to be more probative. ${ }^{288}$ As such, the Indiana Board reduced the property's assessments to $\$ 3,690,000$ for $2010, \$ 3,820,000$ for 2011 , and $\$ 3,680,000$ for 2012. ${ }^{289}$ The Assessor appealed to the Tax Court. ${ }^{290}$

The Tax Court explained the Assessor, on appeal, argued "the Indiana Board's final determination must be reversed because the Meijer, Trimas Fasteners, and Millenium [sic] cases upon which it relied were wrongly decided." ${ }^{291}$ Moreover, the Tax Court stated, "[T]he Assessor believes that, contrary to the Tax Court's holdings in those cases, the sales of properties to secondary users cannot be the type of comparables contemplated under Indiana's market value-in-use standard because they simply do not provide evidence of utility, and thus value, for the 'first generation' user." 292 The Tax Court found the Assessor's argument amounted to an invitation for the Tax Court to reconsider - and ultimately abandon-its holdings in Meijer, Trimas Fasteners, and Millennium. ${ }^{293}$ The Tax Court declined the invitation on the basis of stare decisis. ${ }^{294}$ Further, the Tax Court stated that "the Assessor has done nothing more than express disagreement with the [Tax] Court's decisions in the Meijer, Trimas Fasteners, and Millenium [sic] cases." ${ }^{295}$ As such, the Tax Court affirmed the Indiana Board's final determination. ${ }^{296}$

8. Spencer County Assessor and Grass Township Assessor v. AK Steel Corp. ${ }^{297}$ - AK Steel produces steel at multiple facilities in the Midwest. ${ }^{298}$ AK Steel has blast furnace facilities in Ohio and Kentucky, but none in Indiana. ${ }^{299}$ In Indiana, AK Steel has a finishing facility located in Rockport. ${ }^{300}$ In 2003, the legislature enacted Indiana Code section 6-1.1-3-23-which allowed integrated steel mills the option of using "Pool 5" to value their personal property for taxation purposes. ${ }^{301}$ The legislature later defined an integrated steel mills as "a person, including a subsidiary of a corporation, that produces steel by processing

287. Id. at $915-16$.

288. Id. at 916 .

289. Id.

290. Id.

291. Id. at 918 (citing Meijer Stores Ltd. P'ship v. Smith, 926 N.E.2d 1134 (Ind. T.C. 2010); Stinson v. Trimas Fasteners, Inc., 923 N.E.2d 496 (Ind. T.C. 2010); Millennium Real Estate Inv., LLC v. Benton Cty. Assessor, 979 N.E.2d 192 (Ind. T.C. 2012).

292. Id.

293. Id. at 919.

294. Id.

295. $I d$.

296. Id.

297. 61 N.E.3d 406 (Ind. T.C. 2016), trans. denied, No. 49T10-1306-TA-00057, 2017 WL 1333595 (Ind. Apr. 4, 2017).

298. Id. at 410.

299. Id.

300. $I d$.

301. Id. at $410-11$. 
iron ore and other raw materials in a blast furnace in Indiana., ${ }^{302}$ Although AK Steel did not have a blast furnace, it continued to report its personal property using Pool 5. ${ }^{303}$ The Spencer County Assessor rejected AK Steel's 2008 valuation, "stating that its personal property did not qualify for Pool 5 filing." 304 The PTABOA upheld the Assessor's action. ${ }^{305}$ AK Steel then appealed to the Indiana Board. ${ }^{306}$ The Indiana Board explained the only reason AK Steel was not entitled to Pool 5 was because of the "in Indiana" language. ${ }^{307}$ The Board further explained that "as an administrative agency, it did not have authority to resolve AK Steel's constitutional challenge." ${ }^{308}$ As such, the Indiana Board affirmed the PTABOA. ${ }^{309}$ AK Steel appealed to the Tax Court. ${ }^{310}$

On appeal, AK Steel argued the "in Indiana" language was unconstitutional. ${ }^{311}$ The Assessor, however, contended that even without the "in Indiana" language, AK Steel would not qualify for Pool $5 .{ }^{312}$ The Assessor argued the legislature intended a "person" to mean a "facility" in the definition of an integrated steel mill. ${ }^{313}$ The Tax Court disagreed because the definition went on to say "including a subsidiary of a corporation." 314 Moreover, the Tax Court explained the legislature had amended the statute three times and it could have made the change in one of the amendments if that was its intention. ${ }^{315}$ The Tax Court therefore needed to address AK Steel's constitutional claims. ${ }^{316}$

The Tax Court noted at the outset that AK Steel faced "an extremely high burden of proof on this claim." "317 First, AK Steel argued the "in Indiana" language was unconstitutional under the Equal Protection Clause of the Fourteenth Amendment to the U.S. Constitution. ${ }^{318}$ However, the Tax Court found "the 'in Indiana' language is rationally related to the State's legitimate purpose for creating Pool 5 and that AK Steel has not demonstrated that it is being treated differently than similarly-situated taxpayers." ${ }^{319}$ As such, the Tax

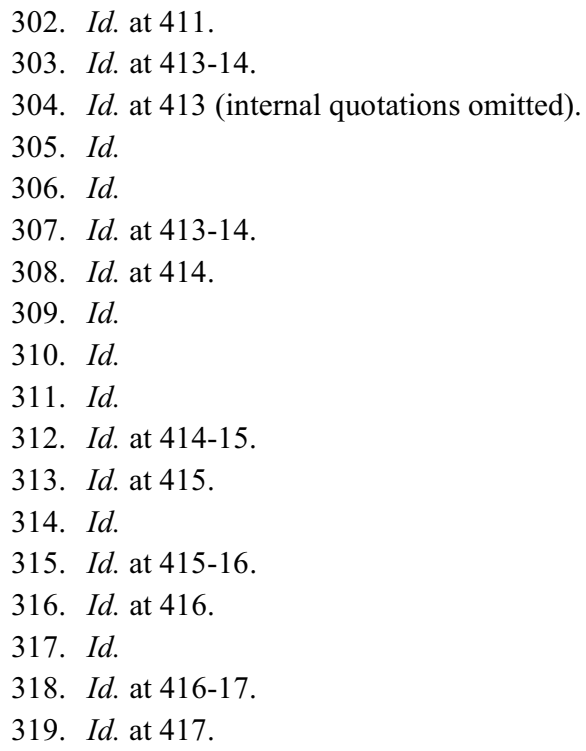


Court found "no violation of AK Steel's federal equal protection guarantees.",320

AK Steel next argued the "in Indiana" language violated the Dormant Commerce Clause by discriminating against interstate commerce. ${ }^{321}$ The Tax Court was not persuaded by that argument because "both domestic and foreign integrated steel mills can claim the benefit of Pool 5 provided they have blast furnaces in Indiana. ${ }^{322}$ Furthermore, the Tax Court explained that entities like AK Steel can still receive tax benefit through a different channel-by appealing their assessment and demonstrating that their personal property suffers from abnormal obsolescence. ${ }^{323}$ AK Steel then asserted that "denying it the use of Pool 5 solely on the basis that its blast furnace is not in Indiana violates its right to substantive due process. ${ }^{, 324}$ However, the Tax Court disagreed and found the government's reason for passing the legislation was neither arbitrary nor unreasonable. ${ }^{325}$ Therefore, the Tax Court found AK Steel's substantive due process claim must fail. ${ }^{326} \mathrm{Next}$, AK Steel argued the "in Indiana" language violated article 4, section 22 of the Indiana Constitution because AK Steel was the only affected company. ${ }^{327}$ The Tax Court disagreed and found the specified class was "reasonably related to carrying out the [Indiana] Legislature's legitimate purpose for creating Pool 5." "328

Finally, AK Steel argued the "in Indiana" language violated article 10, section 1 of the Indiana Constitution. ${ }^{329}$ The Tax Court disagreed and found AK Steel was simply restating their equal protection argument-which the Tax Court had already rejected ${ }^{330}$ Because AK steel did not show the "in Indiana" language was unconstitutional, the Tax Court affirmed the Indiana Board's final determination. ${ }^{331}$

9. Lake County Trust Co., Trust No. 6, (Flowers for Heaven, Inc.) v. St. Joseph County Assessor. ${ }^{332}$ - The Trust appealed a final determination of the Indiana Board. ${ }^{333}$ In its petition, the Trust requested that the Indiana Board prepare the certified administrative record, and the Trust stated it would file the certified administrative record with the Tax Court within thirty days of being notified that it was complete—as required by Tax Court Rule 3(E). ${ }^{334}$ On May 6,

320. Id. at 417-18.

321. Id. at 418 .

322. Id.

323. Id. at 419 .

324. Id. at 420 .

325. Id.

326. $I d$.

327. Id. at 420-21.

328. Id. at 421 .

329. Id.

330. Id.

331. Id. at 422 .

332. 66 N.E.3d 630 (Ind. T.C. 2016).

333. Id. at 630 .

334. Id. (citing IND. TAX CT. R. 3(E)). 
2016, the Indiana Board informed the Trust that the certified administrative record was complete. ${ }^{335}$ On June 23, 2016, both parties attended a case management conference. ${ }^{336}$ Later, on September 1, 2016, "the Trust filed its brief on the merits, but it had not yet filed the certified administrative record. ${ }^{" 337} \mathrm{On}$ September 7, 2016, the Assessor filed a motion to dismiss due to the untimely filing of the certified administrative record. ${ }^{338}$ On September 13, 2016, the Trust responded to the motion and filed the certified administrative record. ${ }^{339}$

The Tax Court explained there was no dispute that the Trust did not timely file the certified administrative record. ${ }^{340}$ The dispositive issue before the Tax Court was "whether the Assessor's motion was itself timely." "341 The Assessor argued that "its objection was timely under Indiana Trial Rule 12(B) because it filed its Motion within 20 days after the Trust filed its brief." ${ }^{342}$ However, the Tax Court explained that a brief is not a pleading; therefore, "Indiana Trial Rule 12(B) does not shelter the Assessor's objection from waiver." ${ }^{343}$ Further, the Tax Court explained the Indiana Supreme Court has found an objection regarding a procedural prerequisite that is not filed timely must be made at the "earliest opportunity." "344 The Tax Court stated that "it follows that the "earliest opportunity' to object must precede the furtherance of the merits." ${ }^{345}$ Therefore, the Tax Court found "an objection to the untimely filing of the certified administrative record in an appeal from a final determination of the Indiana Board must itself be filed before the merits of a case have been furthered." 346 Consequently, because the Assessor here filed the motion after the Trust filed its brief, thereby furthering the merits of the case, the Tax Court held the Assessor waived its objection to the untimely filing of the certified administrative record. ${ }^{347}$

\section{B. Sales and Use Tax}

1. Miller Pipeline Corporation v. Indiana Department of State Revenue. ${ }^{348}$ - Miller Pipeline filed claims with the Department seeking refunds of sale or use tax on certain purchases made in 2005, 2006, and 2007. ${ }^{349}$ The

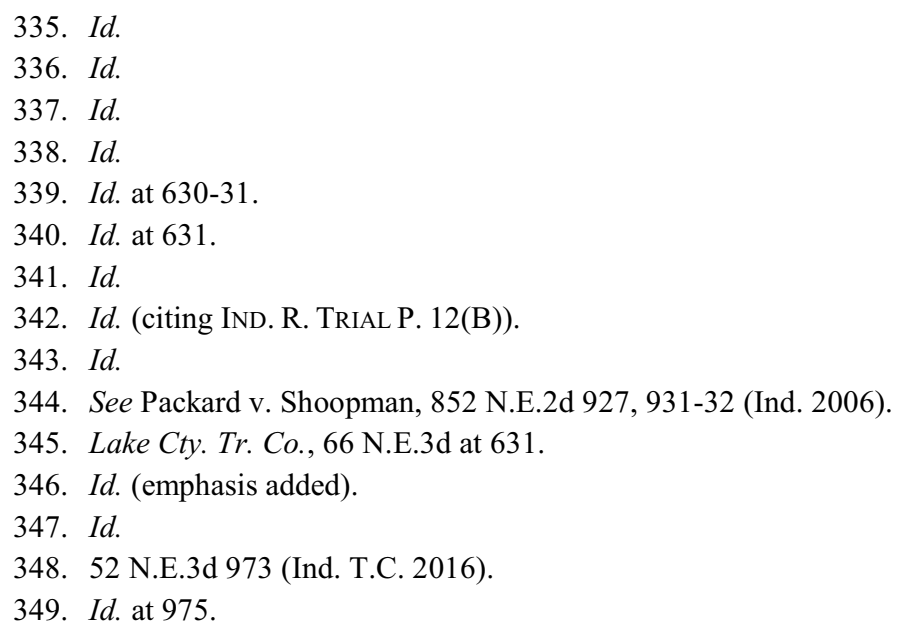


Department determined it would use a statistical sample method to determine the overall liability or refund for 2006 and $2007 .{ }^{350}$ As a result of its statistical sample, the Department issued a proposed assessment totaling $\$ 84,647.96$ for 2006 and 2007..$^{351}$ Miller Pipeline filed another claim seeking a refund in the amount of $\$ 104,318.39$ - apparently believing it was due a refund of $\$ 19,670.43$ for 2006 and 2007. ${ }^{352}$ The Department denied the refund claim. ${ }^{353}$ Miller Pipeline appealed to the Indiana Tax Court. ${ }^{354}$

On appeal, Miller Pipeline challenged "the Department's denial of its March 24, 2010 refund claim," and "the Department's treatment of 29 transactions that were contained within the audit's statistical sample." 355 Miller Pipeline had grouped its arguments into eleven discrete issues, and the Tax Court followed that organization manner. First, Miller Pipeline presented documentation that it paid use tax on two transactions twice. ${ }^{356}$ The Department argued Miller Pipeline did not present any evidence to show they did not later credit itself for the erroneous tax payments. ${ }^{357}$ The Tax Court found Miller Pipeline had rebutted the Department's prima facie evidence, and the Department had the burden to present evidence that demonstrated Miller Pipeline had already credited itself for the erroneous payments. ${ }^{358}$ The Tax Court determined the Department did not produce such evidence; therefore, the Tax Court reversed the Department's proposed assessments on that issue. ${ }^{359}$

Next, Miller Pipeline argued it erroneously remitted use tax on a "casual sale"-which is not subject to taxation. ${ }^{360}$ The Department argued Miller Pipeline did not support its claim that the transaction was a casual sale. ${ }^{361}$ The Tax Court disagreed and found Miller Pipeline had demonstrated that it erroneously paid use tax on the "casual sale" transaction. ${ }^{362}$ Miller Pipeline then argued the Department improperly concluded Miller Pipeline should have remitted use tax on items it won at a silent auction - which had been donated to Distribution Contractors. ${ }^{363}$ Miller Pipeline thus argued that because Distribution Contractors' acquisition of the items was never subject to sales tax, Miller Pipeline's subsequent purchase of the items was not subject to use tax. ${ }^{364}$ The Tax Court found the Department

350. Id.

351. Id. at 976 .

352. $I d$.

353. Id.

354. Id.

355. Id. at 977.

356. Id.

357. Id. at 978 .

358. Id. at 977-78.

359. Id. at 978.

360. Id.

361. Id. at 979 .

362. Id.

363. Id.

364. Id. 
failed to rebut Miller Pipeline's showing and reversed the Department on this issue. $^{365}$

Next, Miller Pipeline argued the Department, for its statistical sample, deemed four lost invoices as entirely taxable. ${ }^{366}$ Miller Pipeline later found the four invoices, but the Department argued Miller Pipeline "was prohibited from presenting those four invoices to the Court during trial." 367 The Tax Court disagreed and reversed the Department's proposed assessments on that issue. ${ }^{368}$ Miller Pipeline then claimed the Department wrongfully determined that a transaction involving its purchase of an air compressor was subject to tax. ${ }^{369}$ Miller Pipeline argued it acquired the air compressor for resale - and therefore it was not a taxable transaction. ${ }^{370}$ The Tax Court determined that "[f]rom this testimony, it is impossible to determine what Miller Pipeline's purpose was in acquiring the subject air compressor." ${ }^{371}$ As such, the Tax Court affirmed the Department's treatment of this transaction. ${ }^{372}$

Next, Miller Pipeline asserted that it made a use tax payment of $\$ 248.98$, and the Department erred by included that use tax again in its statistical sample. ${ }^{373}$ However, the Tax Court found Miller Pipeline's numbers did not "add up," therefore, the Tax Court affirmed the Department on that issue. ${ }^{374}$ On the next issue, Miller Pipeline argued the Department's statistical sampling methodology was erroneous because the Department did not include every item chosen for the sample. ${ }^{375}$ The Tax Court remanded the issue with instructions for the Department to include the skipped items and recompute Miller Pipeline's overall tax liability or refund for 2005 and $2006 .{ }^{376}$

Then Miller Pipeline asserted the Department erroneously included tax that was owed by a contractor, not Miller Pipeline, because the contract was a "lumpsum contract." "377 The Tax Court, however, found Miller Pipeline "ha[d] not provided any evidence demonstrating that the contract was a lump-sum." ${ }^{378}$ As such, the Tax Court affirmed the Department on that issue. ${ }^{379}$ Next, Miller Pipeline argued the Department erred in imposing tax on Miller Pipeline for vendors that were "primarily engaged in the provision of services and their

365. Id. at 980 .

366. Id.

367. Id. at 981 .

368. Id.

369. Id.

370. Id. at 982 .

371. Id.

372. Id. at 983.

373. Id.

374. Id.

375. Id. at $983-84$.

376. Id. at 984 .

377. Id.

378. Id. at 985 .

379. Id. 
charges for materials [were] inconsequential to the overall amounts of their invoices. ${ }^{" 380}$ The Tax Court was not persuaded by this argument because Miller Pipeline did not present any evidence to support the argument. ${ }^{381}$ Therefore, the Tax Court affirmed the Department on that issue. ${ }^{382}$

Miller Pipeline then made essentially the same argument regarding eight different invoices. ${ }^{383}$ Again, the Tax Court affirmed the Department because Miller Pipeline failed to present any evidence to support its position. ${ }^{384}$ Finally, Miller Pipeline argued "it should not have been required to remit tax on [a specific] freight charge because it did not take possession of the tools and supplies in Indiana." 385 The Tax Court found Miller Pipeline rebutted the Department's prima facie evidence because the invoice indicated that the items were to be shipped to Maryland ${ }^{386}$ Further, the Tax Court found the Department failed to provide any rebuttal evidence. ${ }^{387}$ As such, the Tax Court reversed the Department on that issue. ${ }^{388}$

2. Brandenburg Industrial Service Company v. Indiana Department of State Revenue. ${ }^{389}$ - Brandenburg processes and sells metal, demolishes retired assets, performs environmental remediation, and implements site preparation. ${ }^{390}$ Brandenburg acquires metal by either purchasing retired assets or performing demolition and environmental remediation in exchange for the metal. ${ }^{391}$ Further, Brandenburg uses a unique seven-step process that includes: identification, removal, decontamination, cutting, sorting, preparation, and staging. ${ }^{392}$ Brandenburg filed four refund claims with the Department, asserting that various items it used to process metal were exempt from sales and use tax under the Equipment and Consumption Exemptions. ${ }^{393}$ The Department denied all four refund claims and issued proposed assessments that rescinded the Department's

380. Id.

381. Id. at 986 .

382. Id. at 985-86.

383. Id. at 986 .

384. Id.

385. Id. at 986-87.

386. Id. at 987 .

387. Id.

388. Id.

389. 60 N.E.3d 300 (Ind. T.C. 2016). The Indiana Tax Court granted a motion to vacate the trial on March 13, 2017 after the parties tentatively agreed to a settlement. Chronological Case Summary, Brandenburg Indus., 60 N.E.3d 300 (No. 49T10-1206-TA-00037) https://publicaccess. courts.in.gov/docket/Search/Detail?casenumber=49T10-1206-TA-00037 [https://perma.cc/6RGFHLEW] (last visited May 11, 2017).

390. Id. at 301 .

391. Id.

392. Id. at 301-02.

393. Id. at 302. See also IND. CODE § 6-2.5-5-3 (2016) (the Equipment Exemption) and IND. CoDE $\S 6-2.5-5-5.1$ (2016) (the Consumption Exemption). 
prior approval of two of the four claims. ${ }^{394}$ The Department later denied Brandenburg's protest, and Brandenburg appealed to the Indiana Tax Court. ${ }^{395}$

"The Department's claim for partial summary judgment focuse[d] on whether Brandenburg's process 1) falls within the scope of the Equipment and Consumption Exemptions and 2) substantially transforms its raw materials into new, marketable goods ...."396 The Department argued that neither the Equipment nor the Consumption Exemption statutes expressly list the type of demolition process that Brandenburg was engaged in and asserted that these Exemption statutes enumerated a comprehensive list of activities. ${ }^{397}$ The Tax Court, however, explained the list of activities in the Equipment and Consumption Exemption statutes are "an illustrative rather than an exhaustive list." ${ }^{, 398}$ As such, the Tax Court disagreed with the Department and found the Department was not entitled to summary judgment on that issue. ${ }^{399}$

The Department also argued "there [was] no genuine issue of material fact that Brandenburg's seven-step process fail[ed] to create ... distinct, marketable products." ${ }^{400}$ In support of its argument, the Department asserted that no substantial transformation occurs because the seven-step process is "fundamentally destructive" and does not change the intrinsic value or alloy content of the metal. ${ }^{401}$ In response, Brandenburg argued its process is much more than demolition and transforms useless metal into valuable metal. ${ }^{402}$ The Tax Court ultimately agreed with Brandenburg that this process was more than mere demolition. ${ }^{403}$

The Department argued the testimony of Brandenburg's secretary-treasurer and George William Knack, a steel manufacturing expert, both demonstrated that Brandenburg merely released the intrinsic value of the metal but did not actually produce a new product. ${ }^{404}$ However, the Tax Court found neither person's testimony supported the Department's position. ${ }^{405}$ Indeed, the Tax Court determined the "expert testimony explain[ed] that the extracted metal is obsolete, valueless, and unmarketable until Brandenburg transforms it into the end product Brandenburg markets-scrap steel." ${ }^{" 406}$ As such, the Tax Court granted summary judgment to Brandenburg and held "Brandenburg produced scrap steel and is thereby entitled to the Equipment and Consumption Exemptions during the

394. Brandenburg, 60 N.E. $3 \mathrm{~d}$ at 302.

395. Id.

396. Id. at 303 .

397. Id.

398. Id. at 304.

399. Id.

400. Id.

401. Id. at 304-05.

402. Id. at 305 .

403. Id. at 307.

404. Id. at 306-07.

405. Id. at 307.

406. Id. 
period at issue." 407

3. Fresenius USA Marketing, Inc. v. Indiana Department of State Revenue. ${ }^{408}$ - Fresenius appealed the Department's "denial of its claim for refund of gross retail (sales) tax remitted on its sales of durable medical equipment and supplies to Indiana clinics between January 1, 2004, and October 31, 2007 (the Period at Issue)." ${ }^{409}$ The parties filed cross-motions for summary judgment, which presented "one dispositive issue: whether the Department is bound by its published ruling interpreting the exemption provided by Indiana Code $\S 6-2.5-5$ 18 (a). ${ }^{410}$ During the period at issue, Fresenius sold medical equipment to clinics in Indiana that used it to provide "treatment to patients with prescriptions or standing orders from licensed practitioners authorized to issue them." collected sales tax and remitted the tax to the Department. ${ }^{412}$ "On December 16, 2007, Fresenius filed a claim for refund with the Department," which was subsequently denied. ${ }^{413}$ Fresenius appealed to the Tax Court.

The Tax Court explained Indiana's Legislature has exempted certain retail transactions from the imposition of sales tax, including sales of durable medical equipment and medical supplies "if the sales are prescribed by a person licensed to issue the prescription." ${ }^{14}$ Further, the legislature provided the Department authority to interpret the statutes governing the listed taxes, but limited the effect of the Department's interpretations. ${ }^{415}$ The Department, in 1998, "interpreted the predecessor to the Durable Medical Equipment Exemption to apply to sales of medical equipment made to healthcare service providers for treating patients with a prescription." 416 Subsequent to the period at issue, the Department issued two Revenue Rulings. ${ }^{417}$ These rulings again exempted healthcare service providers' purchases of medical equipment and supplies. ${ }^{418}$ However, the Department revoked the Revenue Rulings and replaced them with two new Revenue Rulings that only exempted sales made directly to patients with a prescription. ${ }^{419}$

On appeal, Fresenius argued it was entitled to the exemption because the Department must follow its interpretation of the 1998 Ruling. ${ }^{420}$ The Department

407. $I d$.

408. 56 N.E.3d 734 (Ind. T.C. 2016), trans. denied, No. 49T10-1008-TA-45, 2017 WL 363194

(Ind. Jan. 19, 2017).

409. Id. at 735 .

410. Id.

411. Id.

412. Id.

413. Id.

414. Id. at 736 (quoting IND. CODE § 6-2.5-5-18(a) (2004) (amended 2010) (the Durable Medical Equipment Exemption)).

415. See Ind. CodE $\S 6-8.1-3-3(b)$ (2016).

416. Fresenius, 56 N.E.3d at 736.

417. $I d$.

418. $I d$.

419. Id.

420. Id. at 736-37. 
asserted it was not required to follow the 1998 Ruling because it was not an interpretation of the statutes governing the listed taxes that binds the Department, and the 1998 Ruling was not issued to Fresenius. ${ }^{421}$ To the Department's first argument, the Tax Court was not persuaded because the Department's own regulation interpreting its powers "clarifies that the Department is not limited to interpreting a statute through regulation. ${ }^{" 22}$ Further, the Tax Court explained it had previously addressed this issue and determined the Department may interpret statues governing Indiana's listed taxes by a variety of methods. ${ }^{423}$ Therefore, the Tax Court held the Department was bound by its 1998 Ruling. ${ }^{424}$

The Tax Court also disagreed with the Department's assertion that "only the taxpayer to whom the ruling was issued is entitled to rely on it." ${ }^{.425}$ First, the Tax Court pointed out that Norrell Services, Inc. v. Indiana Department of State Revenue, ${ }^{426}$ which the Department relied on in part, did not address the binding effects of ruling on different taxpayers. ${ }^{427}$ Second, the Tax Court explained that if the legislature had intended Indiana Code section 6-8.1-3-3(b) to "apply only to the taxpayer to whom the published ruling was issued, it could have used the definite article (i.e., 'the' taxpayer) rather than the indefinite article (i.e., 'a' taxpayer). ${ }^{, 228}$ Finally, the Tax Court noted the Department's claim was in contradiction to its own regulation. ${ }^{429}$ Therefore, the Tax Court held that "to the extent Fresenius establishes that its facts are 'substantially identical' to the facts in the 1998 Ruling, the Department is bound to follow it." ${ }^{" 430}$ The Tax Court determined the parties had indeed stipulated Fresenius had facts that were substantially identical to the 1998 Ruling. ${ }^{431}$ As such, the Tax Court granted summary judgment in favor of Fresenius and against the Department. ${ }^{432}$

4. RDM Sales and Service, Inc. v. Indiana Department of State Revenue. ${ }^{433}-$ RDM operated and serviced vending machines and operated two

421. Id. at 737 .

422. Id. (citing 45 Ind. Admin. Code $§ 15-3-2(\mathrm{~d})(1)$ (2004)).

423. Id. (citing Mirant Sugar Creek, LLC v. Ind. Dep't of State Revenue, 930 N.E.2d 697, 700 (Ind. T.C. 2010)).

424. Id.

425. Id. (internal quotations omitted).

426. 816 N.E.2d 517 (Ind. T.C. 2004).

427. Fresenius, 56 N.E.3d at 737-38.

428. Id. at 738 .

429. Id.

430. $I d$.

431. Id.

432. Id. at 739 .

433. 57 N.E.3d 901 (Ind. T.C. 2016). The Indiana Tax Court ordered this matter stayed pending resolution of a Joint Notice of Settlement on February 2, 2017. Chronological Case Summary, RDM Sales \& Serv., Inc., 57 N.E.3d 901 (No. 82T10-1001-TA-00003), https:// publicaccess.courts.in.gov/docket/Search/Detail?casenumber $=82 \mathrm{~T} 10-1001-\mathrm{TA}-00003$ [https://perma.cc/DKX3-YUQP] (last visited May 18, 2017). 
cafeterias at locations owned by third parties. ${ }^{434}$ After an audit, "the Department issued Proposed Assessments of sales tax, interest, and penalties to RDM." ${ }^{435}$ RDM filed a protest with the Department, which was denied. ${ }^{436} \mathrm{RDM}$ then filed an appeal with the Tax Court, and the Department then filed a motion for summary judgment. ${ }^{437}$

On appeal, RDM raised three arguments in response to the Department's prima facie evidence: 1 ) "the Department should be estopped from imposing sales tax on any of its bottled water and fruit juice provided through its vending machines"; 2) certain cafeteria food items were exempted from sales tax; and 3) the Department's negligence penalties should be waived because RDM had reasonable cause to not collect and remit sales tax. ${ }^{438}$

In support of its first argument, RDM stated that bottled water and fruit juice sold in its vending machines was not taxable because the Department's 2004 Sales Tax Clarification excluded those types of items from sales tax; imposing the sales tax on the vending machine food sales, but not on grocery or convenience stores, violated the Equal Protection Clause of the United States Constitution; and "the Proposed Assessments improperly included bottled water and fruit juice dispensed free of charge or at a discounted rate to exempt customers." ${ }^{439}$ The Tax Court found RDM's estoppel argument failed because it based its claim on a misreading of the Department's Clarification. ${ }^{440}$ As to RDM's Equal Protection argument, the Tax Court determined the same argument had already been rejected previously by the Tax Court. ${ }^{441}$ Moreover, the Tax Court explained the new statute did not change the precedential value of $J \& J$ Vending and, to any extent that there is a purported new marketplace, $\mathrm{RDM}$ failed to provide probative evidence to support that argument. ${ }^{442}$ Responding to RDM's final argument, the Tax Court agreed and determined that all of RDM's transactions "providing bottled water and fruit juice free of charge or at a discounted rate to exempt customers [was] not subject to sales tax and must be removed from the Proposed Assessments." 443

RDM next argued that three types of its cafeteria food sales were not taxable: “A) bakery items it sold to customers without providing eating utensils; B) food that it ha[d] cut, repackaged, or pasteurized alone and raw animal foods requiring cooking by the consumer in order to prevent food borne illnesses; and C) food for immediate consumption not sold from its own premises." ${ }^{444}$ The Department

434. Id. at 904 .

435. Id.

436. $I d$.

437. Id.

438. Id. at 905 .

439. Id. at 905-06.

440. Id. at $906-07$.

441. Id. at 907 .

442. Id. at $907-08$.

443. $I d$. at 910 .

444. Id. at 911 . 
argued that eating utensils were provided by the cafeteria owners for sold bakery items, and therefore the sales were taxable under Indiana Code section 6-2.5-520 (b)(3) ${ }^{445}$ Because the Department failed to designate which part of the petition it relied on, there was a genuine issue of material fact regarding who supplied the eating utensils; therefore, the Tax Court held the Department was precluded from summary judgment on this issue. ${ }^{446}$ To the argument of repackaged food, the Tax Court concluded Schlachter's affidavit rebutted the Department's prima facie case; therefore, the Tax Court did not issue summary judgment in favor of the Department on that issue. ${ }^{447}$ RDM also argued it "merely operated the cafeterias ... [and] did not own or otherwise have an interest in those premises, ${ }^{, 448}$ making its sales not taxable. However, the Tax Court explained the word "premise" in the regulation does not refer to ownership, but instead to the place of business. ${ }^{449} \mathrm{As}$ such, the Tax Court found "RDM's cafeteria sales of food for immediate consumption are not exempt under Indiana Code $\S 6-2.5-5-20$ and are subject to sales tax." ${ }^{450}$

Finally, RDM claimed it had reasonably relied on the Department's Clarifications so the Department must waive its negligence penalties. ${ }^{451}$ The Tax Court disagreed, stating that RDM acted unreasonably because "[a] reasonable taxpayer exercising ordinary business care and prudence would not be likely to risk substantial interest and penalties by altering a tax position based on an informal Department publication without investigating more fully." ${ }^{452}$ Because of this, the Department's imposition of negligence penalties was permissible. ${ }^{453}$

5. Orbitz, LLC v. Indiana Department of State Revenue. ${ }^{454}$ - The Department determined Orbitz owed over $\$ 200,000$ in sales tax, innkeeper's tax, and interest for the period between January 1, 2004 and December 31, 2006 because Orbitz collected taxes based on the wholesale rate-instead of the retail rate-of the hotel rooms. ${ }^{455}$ Orbitz filed a protest with the Department, which was denied. ${ }^{456}$ Orbitz then appealed to the Indiana Tax Court, and both parties moved for summary judgment on August 2, 2013. ${ }^{457}$

A retail transaction has been defined as "a transaction of a retail merchant that constitute[d] selling at retail." ${ }^{458}$ Additionally, Indiana imposed several

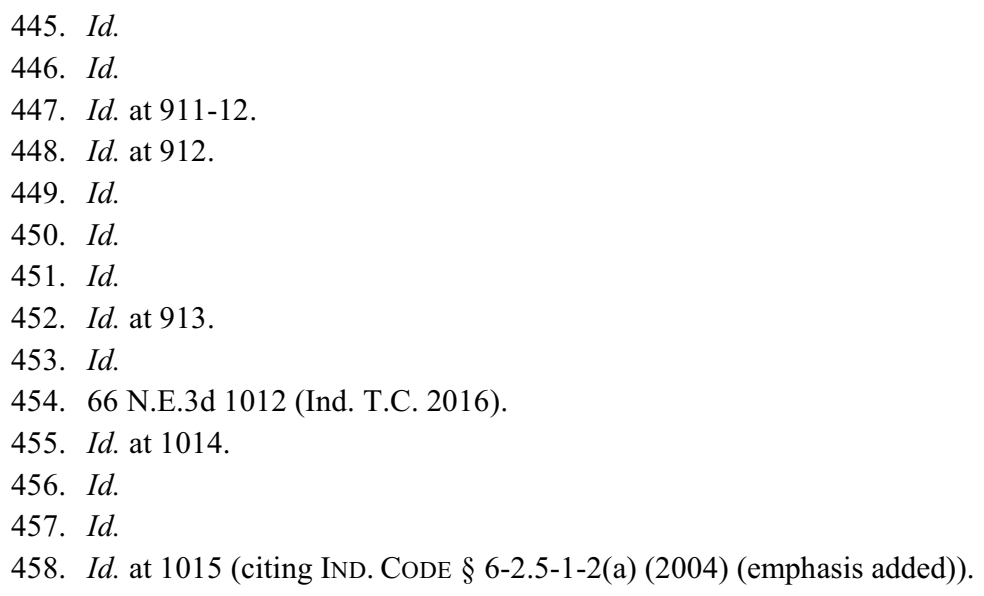


innkeeper's taxes, which differ by county. ${ }^{459}$ Here, "The parties agree that no genuine issues of material fact exist for resolution at trial." ${ }^{260}$ The Tax Court explained the resolution of this dispute involved "two interrelated questions of law: 1) whether Orbitz was a retail merchant during the period at issue; and 2) what was the proper measure of the tax base." "461 To the first question, the Department argued Orbitz was a retail merchant because the Hotel Listing Agreements provided the contracted hotels would hold rooms for Orbitz and Orbitz would market and allow its users to book confirmed, prepaid reservations. ${ }^{462}$ However, the Tax Court determined the Hotel Listing Agreements "merely provided Orbitz with the right to confirm a pre-paid reservation for a hotel room, while the hoteliers themselves, having exclusive possession and control of the rooms, were alone able to transfer possession and control." ${ }^{463}$ Therefore, the Tax Court determined the hoteliers delivered or transferred possession and control of the rooms-not Orbitz. ${ }^{464}$ The Tax Court thus decided Orbitz was "not a retail merchant under Indiana Code $\S$ 6-2.5-4-4(a)." "465

Regarding the proper measure of the tax base, the Department asserted Orbitz should have collected tax calculated from the retail rate because it was a unitary transaction. ${ }^{466}$ Orbitz, however, argued the tax base was properly measured by the wholesale rate because it was not a unitary transaction. ${ }^{467}$ In support of its argument, Orbitz contended Indiana case law limits unitary transactions to "situations where the same retail merchant has provided a customer with both a service and the tangible personal property." ${ }^{.468}$ Therefore, Orbitz argued a unitary transaction did not occur because of a lack of unity between Orbitz's facilitation of the hotel reservation and the actual retail merchant's rental of the hotel room. ${ }^{469}$ The Tax Court resolved that because Orbitz was not a retail merchant, it was relieved of liability for sales or innkeeper's taxes "regardless of the statutory proclamation that each rental or furnishing of a hotel room is a unitary transaction. ${ }^{, 470}$ Consequently, the hoteliers instead were liable for any additional sales or innkeeper's taxes because they were the retail merchants involved in these transactions. ${ }^{471}$ Summary judgment was thus granted in favor of Orbitz. ${ }^{472}$

459. $I d$.

460. $I d$.

461. Id. at 1016 .

462. Id.

463. Id.

464. Id. at 1017 .

465. Id.

466. $I d$.

467. $I d$.

468. Id. (quoting Cowden \& Sons Trucking, Inc. v. Ind. Dep't of State Revenue, 575 N.E.2d

718 (Ind. T.C. 1991)).

469. Id.

470. $I d$.

471. Id.

472. Id. at 1018 . 


\section{Business Tax}

1. Hamilton Southeastern Utilities, Inc. v. Indiana Department of State Revenue. ${ }^{473}$ - In October 2012, Hamilton Southeastern initiated an original tax appeal claiming that its connection fees were not subject to Indiana's utility receipts tax ("URT") under either Indiana Code sections 6-2.3-1-4 or 6-2.3-3$10{ }^{474}$ The Department contended "Hamilton Southeastern's connection fees were taxable gross receipts not only under those statutes, but also under Indiana Code $\S 6-2.3-3-2 .{ }^{\prime 475}$ In August 2015, after the parties filed cross-motions for summary judgment, the Tax Court held "the connection fees were not gross receipts under Indiana Code $\S 6-2.3-1-4 \ldots$ or Indiana Code $\S 6-2.3-3-10 .{ }^{, 476}$ Regarding Indiana Code section 6-2.3-3-2, the Tax Court determined the designated evidence did not show whether "Hamilton Southeastern separated the amount of its connection fees from its taxable receipts on its records," therefore, there remained a genuine issue of material fact. ${ }^{477}$ Hamilton Southeastern then filed a motion for partial summary judgment to resolve the remaining issue. ${ }^{478}$

Hamilton Southeastern argued "its connection fees are not taxable under Indiana Code $\S 6-2.3-3-2$ because they were separated from taxable receipts on its URT returns (i.e., its Forms URT-1). ${ }^{479}$ Hamilton Southeastern designated its Forms URT-1 for the years at issue as support for its argument. ${ }^{480}$ The Tax Court noted the Forms URT-1, line one, required Hamilton Southeastern to provide its taxable receipts received from the retail sale of utility services. ${ }^{481}$ The Tax Court concluded this "necessarily required Hamilton Southeastern to have separated the amount of its nontaxable connection fees from its taxable receipts." ${ }^{\circ 82}$ The Department argued "Hamilton Southeastern did not satisfy the requirements of Indiana Code $\S 6-2.3-3-2$ because the statute requires taxpayers to separately state both their taxable and nontaxable receipts on their returns. ${ }^{\$ 43}$ The Tax Court disagreed, stating that the plain language of the statute did not require the taxpayer to report both nontaxable and taxable receipts on the return. ${ }^{484}$ Furthermore, the Tax Court explained the Department's own Forms URT-1 does not provide a line to report the amount of nontaxable receipts. ${ }^{485}$ As such, the Tax

473. 51 N.E.3d 458 (Ind. T.C. 2016).

474. Id. at 459 .

475. Id.

476. Id.

477. $I d$.

478. $I d$.

479. Id. at 459-60.

480. Id. at 460 .

481. Id.

482. Id.

483. Id.

484. Id. See also IND. CODE $\S 6-2.3-3-2$ (2016).

485. Hamilton, 51 N.E.3d at 460. 
Court held Hamilton Southeastern's connection fees were not subject to the URT because the requirements of Indiana Code section 6-2.3-3-2 were satisfied; therefore, the Tax Court granted summary judgment in favor of Hamilton Southeastern. ${ }^{486}$

2. SBP Petroleum, Inc. v. Indiana Department of State Revenue. ${ }^{487}$ - In 2014, the Department issued a BIA assessment against SBP Petroleum for the 2010 through 2012 tax years (years at issue). ${ }^{488}$ SBP Petroleum protested and the Department denied SBP Petroleum's administrative appeals. ${ }^{489}$ On September 27, 2014, SBP Petroleum, through its president, filed verified petitions asserting the Department incorrectly determined the purported tax liabilities. ${ }^{490}$ On February 26, 2015, the Tax Court approved the parties' case management plan, but on October 8, 2015, the Department filed an agreed motion to vacate the joint case management plan and asked to file a new plan. ${ }^{491}$ The Tax Court received the parties' new case management plan on November 16, 2015, and on January 15, 2016, the Department served SBP Petroleum with a discovery request due within thirty days. ${ }^{492}$

On March 1, 2016, after having missed the deadline, SBP Petroleum sent the Department a document stating " $[\mathrm{p}]$ etitioner is gathering the documents and will provide as soon as possible. ${ }^{\circ 93}$ The Department agreed to give SBP Petroleum more time and SBP Petroleum filed a motion to amend the case management plan. ${ }^{494}$ "On June 2, 2016, the Department sent notices of deposition and subpoenas to SBP Petroleum and its president requiring SBP's designated 30(B)(6) witness and its president to appear for depositions with specific documentation on June 16, 2016." ${ }^{, 45}$ Neither the president nor the $30(\mathrm{~B})(6)$ witness attended the deposition, and in response, the Department filed a motion to dismiss or compel discovery on June $22,2016 .{ }^{496}$ The Department asserted SBP Petroleum's case should be dismissed under Indiana Trial Rule 41(E) because SBP Petroleum had "failed to take any action on its claim for more than 80 days." 497 The next day, SBP Petroleum's attorney filed a motion to withdraw. ${ }^{498}$ The attorney's motion was initially denied but later granted after the attorney provided additional information along with a second motion to

486. Id. at $460-61$.

487. No. 49T10-1409-TA-00057, 2016 WL 5719232 (Ind. T.C. Sept. 29, 2016).

488. Id. at *1.

489. Id.

490. Id.

491. $I d$.

492. Id.

493. Id. (internal quotations omitted).

494. Id.

495. Id.

496. Id. at *1-2

497. Id. at $* 2$.

498. Id. SBP Petroleum's attorney indicated "SBP Petroleum had stopped communicating with him as of March 15, 2016, and had refused to participate in the discovery process." Id. 
withdraw. ${ }^{499}$ The Tax Court advised SBP Petroleum to obtain new counsel by August 8, 2016. ${ }^{500}$

Subsequently, the Tax Court scheduled a Trial Rule 41(E) hearing, which neither SBP Petroleum nor its president attended. ${ }^{501}$ The Tax Court stated that the case had been pending on the docket for 634 days and that SBP Petroleum had violated Trial Rules 30 and $34 .^{502}$ Further, the Tax Court declared that not even the Trial Rule 41(E) hearing spurred SBP Petroleum or its president into action, thus deciding to dismiss SBP Petroleum's case with prejudice in a memorandum decision. ${ }^{503}$

3. Thor Industries, Inc. and Subsidiaries v. Indiana Department of State Revenue. ${ }^{504}$ - Thor initiated a tax appeal challenging the Department's proposed assessments of additional AGIT, interest, and penalties. ${ }^{505}$ On June 9, 2016, "the Department served Thor with its First Request for Admissions," asking Thor to repudiate the allegations within thirty days. ${ }^{506}$ "On July 18, 2016, after the time for responding lapsed, the Department contacted Thor to inquire about the status of its response." ${ }^{, 507}$ The Department then moved for summary judgment four days later. "508 "On July 27, 2016, Thor filed a Motion to Withdraw Admissions and Request for Oral Argument." 509 The Tax Court explained, "The party seeking withdrawal has the burden of demonstrating that the presentation of the merits will be subserved by withdrawal, and the party who has obtained the admissions has the burden of demonstrating that it will be prejudiced if the [ ] court permits withdrawal." 510 Moreover, the Tax Court explained that even when both conditions are satisfied, "the Rule does not compel the Court to grant withdrawal or amendment." ${ }^{511}$

Thor asserted "the presentation of the merits will be subserved by the

499. Id.

500. Id.

501. $I d$.

502. Id. at *3.

503. Id.

504. 60 N.E.3d 308 (Ind. T.C. 2016). The Indiana Tax Court ordered the parties to file a joint stipulation of dismissal with the Indiana Tax Court on or before May 8, 2017. After the parties filed their joint stipulation of dismissal, the Indiana Tax Court dismissed the action with prejudice on May 17, 2017. Chronological Case Summary, Thor Industries, Inc., 60 N.E.3d 308, https:// publicaccess.courts.in.gov/docket/Search/Detail?casenumber=49T10-1508-TA-00027 [https://perma.cc/Q4F9-B3L4] (last visited May 18, 2017).

505. Id. at 310 .

506. $I d$.

507. Id.

508. Id.

509. Id.

510. Id. (quoting Cross v. Cross, 891 N.E.2d 635, 640 (Ind. Ct. App. 2008) (internal citation omitted)).

511. Id. (citing Gen. Motors Corp., Chevrolet Motor Div. v. Aetna Cas. \& Sur. Co., 573 N.E.2d 885, 889 (Ind. 1991)). 
withdrawal of its admissions because it would prevent the litigation from ending without addressing matters that are the basis of the Department's Proposed Assessments. ${ }^{~}{ }^{12}$ In response, the Department argued Thor cannot meet its burden by merely claiming that the admissions concern the core issues or by making a blanket request for withdrawal. ${ }^{513}$ In support of its argument, the Department cited Bryant v. County Council of Lake County. ${ }^{514}$ The Tax Court, however, relied on a more recent Court of Appeals decision clarifying that a litigant may meet its burden by showing the admitted matters concern the core issues of the case..$^{515}$ Consequently, the Tax Court was not persuaded by the Department's argument. ${ }^{516}$ The Department also rejoined that Thor's blanket requests for the withdrawal of deemed admissions were prohibited by Trial Rule 36(A), but the Tax Court found the language of Trial Rule 36(A) did not support this claim. ${ }^{517}$

Next, the Tax Court determined whether the withdrawal would prejudice the Department, which had claimed it would be prejudiced by the withdrawal "because it places the viability of its motion for summary judgment at issue by triggering a sudden need for witnesses and evidence to support matters that the Department thought were firmly established.. ${ }^{518}$ Moreover, the Department claimed it would be deprived of a fair opportunity to conduct discovery because of the deadlines under the case management plan, but the Tax Court disagreed. ${ }^{519}$ The Tax Court wrote that the Department's "hasty motion for summary judgment suggests that its reliance on the deemed admission was unreasonable" because "both parties knew that the subject matter of each deemed admission was intended for litigation. ${ }^{, 520}$ The Tax Court was also persuaded by the fact that Thor promptly sought withdrawal of all of the deemed admissions. Because the Department's reliance on the deemed admissions was unreasonable, the Department did not establish it would be prejudiced by the withdrawal of the admissions. ${ }^{521}$ Moreover, the Tax Court determined the Department's use of Trial Rule 36(B) contravened the Rule's purpose and instead granted Thor's motion to withdraw admissions. ${ }^{522}$

4. University of Phoenix, Inc. v. Indiana Department of State

512. Id.

513. Id.

514. Id. at 311 (citing Bryant v. Cty. Council of Lake Cty., 720 N.E.2d 1, 6 (Ind. Ct. App. 1999)).

515. Thor Industries, Inc., 60 N.E.3d at 311 (citing Costello v. Zavodnik, 55 N.E.3d 348 (Ind. Ct. App. 2016)). The Tax Court also explained, although persuasive, the Court of Appeals' decisions are not controlling authority that binds the Tax Court. Id.

516. $I d$.

517. Id.

518. Id. at 312 (internal quotations omitted).

519. Id.

520. Id. at 312-13.

521. Id. at 313 .

522. Id. 
Revenue. ${ }^{523}$ - The University of Phoenix ("UoPX”) appealed the Department's assessment of AGIT and interest, arguing the Department incorrectly computed its alleged tax liability by failing to source its online tuition service revenue based on the costs of performance test. ${ }^{524}$ On October 21, 2016, the Department filed a motion asking the Tax Court to bar or reschedule a subpoenaed deposition of the former Commissioner of the Department, Michael Alley, but the Tax Court quashed the subpoena. ${ }^{525}$ "On November 1, 2016, UoPX sent a second subpoena to $\mathrm{Mr}$. Alley, requesting that he appear for a deposition on November 29, 2016. ${ }^{, 526}$ UoPX sought the deposition to discuss, among other topics, the Tax Competitiveness and Simplification Report of September 2014 (the "Report"), Mr. Alley's presentation on the Report, section 14 of House Bill 1349, and the Department's position on costs of performance sourcing. ${ }^{527}$ On November 10 , 2016, the Department filed its Verified Motion for Protective Order, claiming the protective order would "shield Mr. Alley from annoyance, oppression, and the undue burden and expense of the deposition because UoPX seeks information not relevant to the issues in this case. ${ }^{, 528}$ Moreover, the Department argued the protective order was merited because UoPX had "already deposed three other competent witnesses, obtained testimony on the deposition topics, and admitted it would not question Mr. Alley about the actual issues in this case." ${ }^{529}$

The Tax Court explained one of the issues raised in UoPX's petition was whether, with respect to sourcing online tuition service revenue, Indiana Code section 6-3-2-2 "allowed for the use of a market or customer-based sourcing test or mandated the use of the costs of performance test alone." determined, although Mr. Alley was not the Commissioner during the relevant period, the Report, Mr. Alley's presentation, and House Bill 1349 contained information about both of the tests. ${ }^{531}$ Therefore, the Tax Court held the deposition topics were relevant to the subject matter in the case. ${ }^{532}$ Furthermore, the Tax Court determined it was reasonable to believe that Mr. Alley, a former Commissioner, could provide additional information on the deposition topics, explaining that although high-ranking government officials should not ordinarily be compelled to testify, this precedent was not relevant here because Mr. Alley

523. 64 N.E.3d 1271 (Ind. T.C. 2016). The trial on this matter was held on February 28 and March 1, 2017. Chronological Case Summary, Univ. of Phoenix, Inc., 64 N.E.3d 1271, https://publicaccess.courts.in.gov/docket/Search/Detail?casenumber=49T10-1411-TA-00065 [https://perma.cc/5JSL-Q2Q3] (last visited May 18, 2017).

524. Id. at 1272 .

525. Id. The Tax Court however "advised the parties that UoPX could depose Mr. Alley at a later date." Id.

526. Id.

527. Id.

528. Id. at 1273.

529. Id.

530. $I d$.

531. Id. at 1274 .

532. Id. 
was no longer the Commissioner. ${ }^{533}$ For those reasons, the Tax Court denied the Department's motion for a protective order. ${ }^{534}$

\section{Individual Income Tax}

1. Popovich v. Indiana Department of State Revenue: Order on Request for Expenses Related to Popovich's First Motion to Compel. ${ }^{535}$ - On February 20, 2012, ten days before the hearing on Popovich's first motion to compel, the Indiana Tax Court ordered the Department to provide "a discrete and numbered list of each item it sought to be protected from discovery." 536 The Department raised "about 418 separate objections to nearly all of Popovich's interrogatories and requests for production." ${ }^{537}$ The Department claimed "Popovich's discovery requests were not relevant"; "violated both the deliberative process privilege and the general bar against probing the mental processes of administrative decisionmakers"; "violated the work-product and attorney-client privileges"; and "were oppressive, ambiguous, and unduly burdensome; contained compound questions; posed hypothetical questions; and improperly sought legal conclusions. ${ }^{" 338} \mathrm{On}$ April 24, 2014, the Tax Court rejected all of the Department's claims because the Department "had done nothing more than assert a series of blanket objections." 539

Popovich requested expenses, in accordance with Indiana Trial Rule $37(\mathrm{~A})(4)$, of $\$ 51,210.29$ for successfully prosecuting his first motion to compel. ${ }^{540}$ The Tax Court conducted the hearing on his first motion to compel on October $22,2014 .^{541}$ In considering whether to award him expenses, the Tax Court noted that "when a discovery enforcement motion ... is granted or denied, a presumption arises that the [Tax] Court will order the reimbursement of the prevailing party's reasonable expenses." ${ }^{\circ 42}$ The award is mandatory unless the losing party demonstrates "he was substantially justified in making or opposing

533. $I d$.

534. Id.

535. 50 N.E.3d 407 (Ind. T.C. 2016).

536. Id. at 409 .

537. Id.

538. Id. at 410 .

539. Id. See also Popovich v. Ind. Dep't of State Revenue, 7 N.E.3d 406 (Ind. T.C. 2016) [hereinafter Popovich I].

540. Popovich, 50 N.E.3d at 409; see also InD. R. TRIAL P. 37(A)(4) ("If the motion is denied, the court shall, after opportunity for hearing, require the moving party or the attorney advising the motion or both of them to pay to the party or deponent who opposed the motion the reasonable expenses incurred in opposing the motion, including attorney's fees, unless the court finds that the making of the motion was substantially justified or that other circumstances make an award of expenses unjust.”).

541. Id. at 410 .

542. Id. at 411; see also Penn Cent. Corp. v. Buchanan, 712 N.E.2d 508, 511 (Ind. Ct. App. 1999). 
the motion" or demonstrates the award of expenses is unjust. ${ }^{543}$

The Department argued it was substantially justified in opposing Popovich's discovery request because its objections "were supported by citations to authority and cogent argument." ${ }^{, 544}$ Further, the Department contended, although it may have made some objections with a "broad brush," "its lack of specificity was substantially justified because it is a common practice in discovery for parties to make . . . certain objections broadly." 545 Popovich argued the Department's noncompliance was not justified because the claims were not supported by any substantial rationale. ${ }^{546}$ The Tax Court found the Department was substantially justified in opposing Popovich's first motion to compel based on three of its objections: relevance, the deliberative process privilege, and the general bar against probing the mental processes of administrative decision-makers. ${ }^{547}$ However, the Tax Court explained the Department was not substantially justified in opposing Popovich's discovery requests by raising blanket objections. ${ }^{548}$

The Department further argued Popovich's request for expenses was unreasonable because it did not adequately account for the Department's partial success, it did not encompass the proper time frame for calculating expenses, and it included expenses that were incurred for another case. ${ }^{549}$ The Tax Court found the general bar against probing the mental process "was not at issue in Popovich $I$ because the Indiana Supreme Court had already determined that the general bar existed. ${ }^{550}$ Therefore, the Tax Court explained the Department did not have the claimed partial success in Popovich $I^{551}$ In regard to the proper time frame, the Tax Court found the Popovich's reimbursement period began on the day the Department responded to his first discovery requests and ended on the day of the hearing on Popovich's request expenses. ${ }^{552}$ The Tax court determined the Department had not established that Popovich's request for expenses was based on expenses incurred outside of the relevant time frame. ${ }^{553}$

Finally, the Tax Court considered the Department's argument that Popovich's request included expenses for a different case ${ }^{554}$ Popovich agreed the request for expenses included expenses for another case but "claim[ed] the inclusion [was] proper because the issue in the other case dealt with one of the same issues in Popovich I. ${ }^{, 555}$ The Tax Court found the inclusion of expenses from a different

543. Popovich, 50 N.E.3d at 411.

544. Id.

545. Id. (internal quotation marks and citation omitted).

546. Id.

547. Id. at 412 .

548. Id.

549. Id. at 412-13.

550. Id. at 413 .

551. Id.

552. Id. at 414 .

553. Id.

554. Id.

555. Id. 
case caused the request for expenses, in the full amount, to be unreasonable. ${ }^{556}$ In determining a reasonable amount of expenses, the Tax Court considered the credibility of Popovich's evidence, the relative success of both parties, and the conduct of both parties - which resulted in an unnecessarily prolonged discovery process. ${ }^{557}$ The Tax Court held the Department must pay Popovich for his reasonably incurred expenses of $\$ 24,963 .{ }^{558}$

2. Popovich v. Indiana Department of State Revenue: Order on Request for Expenses Related to Popovich's Second Motion to Compel. ${ }^{559}$ - "In December of 2011, Popovich subpoenaed the Department's designated Trial Rule 30(B)(6) witness, directing him to bring several pages of original documentation to a deposition." ${ }^{560}$ The Department responded to Popovich and explained it would bring only copies of the requested documentation. ${ }^{561}$ Popovich responded by stating that he would file another motion to compel if the Department did not bring the original documentation. ${ }^{562}$ After the Department's witness appeared at the deposition without any original documentation, Popovich quickly adjourned the deposition. ${ }^{563}$ In January 2012, Popovich filed his second motion to compel. ${ }^{564}$

On April 24, 2012, the Tax Court denied Popovich's second motion to compel because Popovich failed to document his attempts to resolve the matter informally-a requirement of Indiana Trial Rule 26(F). ${ }^{565}$ Popovich filed a subsequent motion to reconsider, arguing the Department's behavior "had made complying with Trial Rule 26(F) futile." ${ }^{566}$ The Tax Court denied that motion. ${ }^{567}$

The Tax Court, on October 22, 2014, conducted a hearing on the Department's request for expenses - as required by Indiana Trial Rule $37(\mathrm{~A})(4) .{ }^{568}$ Popovich argued "he was substantially justified in filing his second motion to compel original documents because he only sought to recover the costs from the canceled deposition that was caused by the Department's malfeasance." ${ }^{569}$ Specifically, Popovich argued the Department ignored his subpoena, "failed to avail itself of the motion to quash remedy," and did not comply with his subpoena until the "eleventh hour." that if he had more clearly crafted his argument as a Trial Rule 45(F) motion, he

556. $I d$.

557. $I d$.

558. Id. at 415 .

559. 50 N.E. $3 \mathrm{~d} 415$ (Ind. T.C. 2016).

560. Id. at 416 .

561. Id.

562. Id.

563. Id.

564. Id.

565. Id.; see also IND. R. TRIAL P. 26(F).

566. Popovich, 50 N.E.3d at 416.

567. Id.

568. Id.; see also IND. R. TRIAL P. 37(A)(4).

569. Popovich, 50 N.E.3d at 417.

570. Id. 
would have likely prevailed. ${ }^{571}$ The Tax Court explained Popovich cannot elude the requirements of Indiana Trial Rule $26(\mathrm{~F})$ on the basis that he meant to file a different motion or by shifting the blame to the Department. ${ }^{572}$ In regard to Popovich's attempt to shift the blame to the Department, the Tax Court stated that "a reasonable person could not conclude the Department's mulish behavior relieved Popovich from complying with the requirements of Trial Rule 26(F)." Consequently, the Tax Court held Popovich was not substantially justified in filing his second motion to compel. ${ }^{574}$ Popovich did not question the reliability or reasonableness of the Department's requested amount of expenses; therefore, the Tax Court found Popovich must pay the Department's expenses of $\$ 5,175.25 .^{575}$

3. Popovich v. Indiana Department of State Revenue: Order on Department's Motion for Summary Judgment. ${ }^{576}$ - The Department filed a summary judgment for two issues: whether the Department's 2003 adjusted gross income tax (AGIT) assessment was timely and whether Popovich was a professional gambler eligible for certain deductions. ${ }^{577}$ On December 29, 2007, the Department rejected Popovich's contention that he was engaged in the trade or business of gambling in 2003 and $2004 .^{578}$ As such, the Department issued proposed assessments for $\$ 403,762.72$ for additional AGIT due, as well as interest and penalties. ${ }^{579}$ Popovich protested, but the Department upheld the assessment. ${ }^{580}$ Popovich then initiated an original tax appeal challenging the additional AGIT and interest for 2003 and 2004 tax years and the imposition of negligence penalties for all of the tax years at issue. ${ }^{581}$ The Department moved for summary judgment under Indiana Trial Rule 56(C) ${ }^{582}$

The Indiana Tax Court explained that because the Department had moved for summary judgment and properly designated its proposed assessments as evidence, it had made a prima facie case. ${ }^{583}$ Therefore, the burden shifted to Popovich. ${ }^{584}$ As a preliminary matter, the Tax Court considered two pieces of evidence designated by Popovich that the Department argued were inadmissible. First, the Department argued the court should disregard Popovich's affidavit because it contradicts statements Popovich made during discovery, it is internally

571. Id; see also InD. R. TRIAL P. 45(F).

572. Popovich, 50 N.E.3d at 417-18.

573. Id. at 418 .

574. Id.

575. Id.

576. 52 N.E.3d 73 (Ind. T.C. 2016).

577. Id. at 75 .

578. $I d$.

579. Id.

580. $I d$.

581. Id.

582. Id. See also Ind. R. TRial P. 56(C).

583. Popovich, 52 N.E.3d at 76.

584. Id. 
inconsistent, contains conclusory statements, and puts Popovich's credibility at issue. ${ }^{585}$ The Tax Court determined the Department did not support these assertions and instead merely identified differences between Popovich's characterization of the evidence and the Department's; accordingly, the Tax Court did not find Popovich's affidavit inadmissible. ${ }^{586}$ Second, the Department contended Boskett's report only showed that Boskett is an expert in casinos and not on professional gambling. ${ }^{587}$ The Tax Court found Popovich did not "lay a proper foundation to show Boskett's expertise regarding professional gambling." ${ }^{588}$ Therefore, the Tax Court did not consider Boskett's report in resolving the summary judgment motion. ${ }^{589}$

To rebut the prima facie case by the Department, Popovich contended there was a genuine issue of material fact whether the 2003 proposed assessment was timely. ${ }^{590}$ The Department stated that Popovich's 2003 income tax return was mailed to the Department on February 1, 2005. ${ }^{591}$ The Department asserted it issued the proposed assessment on January 28, 2008, well within the three year limit under Indiana Code section 6-8.1-5-2(a) ${ }^{592}$ Alternatively, the Department argued no statute of limitations governed because Popovich's late return was "the legal equivalent of no return at all. ${ }^{, 593}$ Popovich argued his 2003 income tax return was mailed to the Department on January 10,2005. ${ }^{594}$ The Tax Court found the envelope referenced by the Department actually belonged to Popovich's former wife and not Popovich himself. ${ }^{595}$ Furthermore, the Tax Court explained the Department was incorrect in its assertion that a late return is treated as the equivalent of having never filed a return at all. ${ }^{596}$ The Tax Court determined the only reasonable inference to be drawn was that Popovich filed his return on January 10, 2005, which was the date it was signed and mailed. ${ }^{597}$ The Tax Court also noted both parties agreed that the Department issued its 2003 proposed assessment on January 28, 2008. ${ }^{598}$ Consequently, the Tax Court found the 2003 proposed assessment was not timely issued and thus void. ${ }^{599}$ Further, the court, sua sponte, granted summary judgment on the issue to Popovich, under Indiana

585. $I d$.

586. Id.

587. Id. at 76-77.

588. Id. at 77 .

589. Id.

590. $I d$.

591. Id.

592. Id.; see also IND. CoDE $\S 6-8.1-5-2$ (a) (2016).

593. Popovich, 52 N.E.3d at 77 (internal quotation marks and citation omitted).

594. Id.

595. Id.

596. Id. at 78 .

597. Id.

598. Id.

599. Id. 
Trial Rule 56(B) ${ }^{600}$

Finally, the Department argued Popovich was not eligible to deduct expenses incurred while playing blackjack in 2004 from his income because he was not a professional gambler ${ }^{601}$ The Regulations provide a non-exhaustive list of factors to be weighed when determining whether a taxpayer is engaged in gambling with the purpose of making a profit. ${ }^{602}$ The Tax Court noted the factors include:

(1) The manner in which the taxpayer carries on the activity; (2) the expertise of the taxpayer or his advisers; (3) the time and effort expended by the taxpayer in carrying on the activity; (4) the expectation that assets used in the activity may appreciate in value; (5) the success of the taxpayer in carrying on other similar or dissimilar activities; (6) the taxpayer's history of income or losses with respect to the activity; (7) the amount of occasional profits, if any, which are earned; (8) the financial status of the taxpayer; and (9) the elements of personal pleasure or recreation. ${ }^{603}$

The Tax Court noted it had recently explained "that it will not grant summary judgment to any party when the evidentiary presentations require it to resolve factual disputes and conflicting inferences, assess a witness's credibility, or determine where the preponderance of the evidence lies before it has been fully presented. ${ }^{" 604}$ Because the summary judgment motion would require exactly those types of judgment calls, the Tax Court denied summary judgment to that issue. ${ }^{605}$ In summation, the Tax Court granted summary judgment to Popovich with respect to the untimeliness of the Department's 2003 proposed assessment and denied summary judgment on the issue of whether Popovich was a professional gambler for the 2004 tax year. ${ }^{606}$

4. Von Erdmannsdorff v. Indiana Department of State Revenue: Order on Motions to Strike ${ }^{607}$ - The Tax Court in this case issued a Memorandum Decision that granted the von Erdmannsdorffs' motions in part and denied them in part. ${ }^{608}$ The von Erdmannsdorffs moved to strike certain statements and designated evidence that supported the Department's motion for summary judgment. ${ }^{609}$ Specifically, the von Erdmannsdorffs' claimed two depositions, evidence regarding their tax return, their inventory records, and BizStats were not

600. Id.; see also IND. R. TRIAL P. 56(B).

601. Popovich, 52 N.E.3d at 79-80.

602. Id. at 79 .

603. Id.

604. Id. at 80; see also Elmer v. Ind. Dep't of State Revenue, 42 N.E.3d 185, 197 (Ind. T.C. 2015).

605. Popovich, 52 N.E.3d at 80.

606. Id.

607. No. 49T10-1112-TA-00093, 2016 WL 3186546, (Ind. T.C. June 3, 2016) (unpublished disposition).

608. Id. at *1-2

609 . Id. at $* 1$. 
admissible ${ }^{610}$ First, the von Erdmannsdorffs' claimed the deposition of John von Erdmannsdorff and Kurk Bright must be disregarded because they were not published. ${ }^{611}$ The Tax Court explained that the "filing of any deposition amounts to its 'publication." "'612 Accordingly, because the Tax Court had determined the Department filed both depositions, the Tax Court declined to strike the von Erdmannsdorff and Bright depositions. ${ }^{613}$

Second, the von Erdmannsdorffs claimed that statements and designated evidence regarding purported failure to file income taxes for dates prior to the years at issues "must be stricken as not relevant." information was relevant because it showed a pattern of noncompliance and careless recordkeeping. ${ }^{615}$ The Tax Court determined the von Erdmannsdorffs' purported failure to file income tax returns for the dates prior to the years at issue was not relevant because "that fact will not aid in the resolution of the Department's summary judgment motion." ${ }^{\prime 616}$ As such, the Tax Court held it would not consider that fact in resolving the Department's motion. ${ }^{617}$

Next, the von Erdmannsdorffs contended "the Department's statements regarding their purported failure to provide inventory records to the Department are inconsistent with the von Erdmannsdorffs' designated evidence and, thus, must be stricken." ${ }^{\prime 618}$ The Tax Court found the von Erdmannsdorffs' claim showed the parties merely characterized the facts differently; therefore, the Tax Court declined to strike the statements. ${ }^{619}$

Finally, the von Erdmannsdorffs argued the Department's statements regarding BizStats were not supported by the designated evidence and must be stricken. ${ }^{620}$ The Tax Court denied the von Erdmannsdorffs' motion to strike the statements regarding BizStats because the Tax Court found the information on the website supported the Department's statements. ${ }^{621}$

5. Von Erdmannsdorff v. Indiana Department of State Revenue: Order on Motions for Summary Judgment. ${ }^{622}$ - Mr. von Erdmannsdorff operated a sole proprietorship, Von's Shops, and a real property rental business. ${ }^{623}$ The Department conducted an income tax audit of Von's Shops and subsequently used BIA to calculate the von Erdmannsdorffs Indiana AFIT liabilities for the tax

610. Id.

611. Id.

612. Id. at *2 (quoting IND. R. TRIAL. P. 5(E)(5)).

613. Id.

614. Id. at *1.

615. Id.

616. $I d$.

617. $I d$.

618. Id. at *2.

619. Id.

620. $I d$.

621. Id.

622. 53 N.E.3d 621 (Ind. T.C. 2016).

623. Id. at 622 . 
years 2000-2009 (the years at issue). ${ }^{624}$ "[T]he Department issued BIA Assessments to the von Erdmannsdorffs in the amount of $\$ 244,686.87$ for additional AGIT, interest, and penalties. ${ }^{, 625}$ The von Erdmannsdorffs filed a protest and provided, among other things, inventories of Von's Shops. ${ }^{626}$ The Department upheld the BIA assessments and later denied the von Erdmannsdorffs' request for rehearing. ${ }^{627}$ The von Erdmannsdorffs appealed to the Tax Court. ${ }^{628}$ The Department filed a motion for summary judgment, and the von Erdmannsdorffs filed a counter-motion for summary judgment. ${ }^{629}$ The Tax Court restated the two issues as:

I) $[w]$ hether the von Erdmannsdorffs rebutted the presumption of correctness afforded to the Department's [BIA] assessments; and if so, II) $[w]$ hether the Department erred in calculating the von Erdmannsdorffs' Indiana adjusted gross income by combining the gross receipts but failing to account for the additional business expense deductions. ${ }^{630}$

To the first issue, the von Erdmannsdorffs argued their estimates for cost of goods sold rebutted the Department's prima facie case. ${ }^{631}$ The Department argued the von Erdmannsdorffs' estimates were generated after the tax years at issue and were based "on guesses originating from decade-old memories." ${ }^{632}$ Further, the Department argued Allied Collections Services, Inc. v. Indiana Department of State Revenue ${ }^{633}$ supported its proposition that the Tax Court may entirely disregard untrustworthy estimates-such as the von Erdmannsdorffs cost of goods estimates. ${ }^{634}$ However, the Tax Court found "[n]othing within [Indiana Code section 6-8.1-5-4] expressly precludes taxpayers from offering evidence generated post audit. ${ }^{, 635}$ Further, the Tax Court found the Allied Collections opinion did not stand for the proposition that the Department stated. ${ }^{636}$ The Tax Court found the issue could not be resolved by summary judgment because "the

624. Id. at 623. ("The Department discovered that the von Erdmannsdorffs had not filed any federal or state income tax returns and expanded its audit to include all of the years at issue.").

625. Id.

626. Id.

627. Id. at 623-24.

628. Id. at 624 .

629. Id.

630. Id. at 622 .

631. Id. at 624 .

632. Id. at 625 (internal quotation marks and citation omitted).

633. 899 N.E.2d 69 (Ind. T.C. 2008).

634. Von Erdmannsdorff, 53 N.E.3d at 625.

635. Id.; see also IND. CODE $§ 6-8.1-5-4$ (2016).

636. Von Erdmannsdorff, 53 N.E.3d at 625 ("In Allied Collections, the Court did not simply disregard the designated evidence because it was untrustworthy, as the Department has claimed. Instead, the Court determined that because the credibility of the designated evidence was at issue, summary judgment was inappropriate."). 
parties vigorously dispute the credibility of each other's designated evidence." ${ }^{637}$

The von Erdmannsdorffs claimed they were entitled to partial summary judgment because the Department improperly computed their adjusted gross income by "combining the gross receipts of Von's Shops and the rental business" and "failing to account for all of the substantiated expense deductions." ${ }^{3638}$ In response, the Department argued the motion should be denied because the errors were harmless and resulted in a decrease in the von Erdmannsdorffs' adjusted gross income for the years at issue. ${ }^{639}$ The Tax Court explained "the critical question is whether the Department's methodology comports with the law." The Tax Court found the parties agreed that the Department's methodology did not comport with the law. ${ }^{641}$ As such, the Tax Court found the von Erdmannsdorffs were entitled to partial summary judgment on that issue. ${ }^{642}$

\section{E. Inheritance Tax: Indiana Department of State Revenue, Inheritance Tax Division v. The Estate of Orville J. Rauch ${ }^{643}$}

Rauch was born in 1930 , never married, and had no children. ${ }^{644}$ Rauch owned farmland in Illinois and farmed most of his life ${ }^{645}$ Around the early $1970 \mathrm{~s}$, Rauch befriended two neighbor children: Robert Wandless, age ten, and Claudia L'Ecuyer, age twelve ${ }^{646}$ Rauch treated the children much like a father would treat his children ${ }^{647} \mathrm{He}$ gave them advice, direction, and correction. ${ }^{648}$ "Robert and Claudia married when they were 19 years old." ${ }^{649}$ When Robert and Claudia had children, Rauch called them "his grandchildren." ${ }^{650}$ Rauch decided to sell his Illinois farmland and purchased farmland in Indiana with the proceeds. ${ }^{651}$ Rauch, Robert, Claudia, and their children then moved to Indiana ${ }^{652}$ Upon his death in October 2010, Rauch left the majority of his estate to Robert and Claudia. ${ }^{653}$

"On September 29, 2011 Orville's Estate filed its inheritance tax return reporting, among other things, that Robert and Claudia were his children in loco

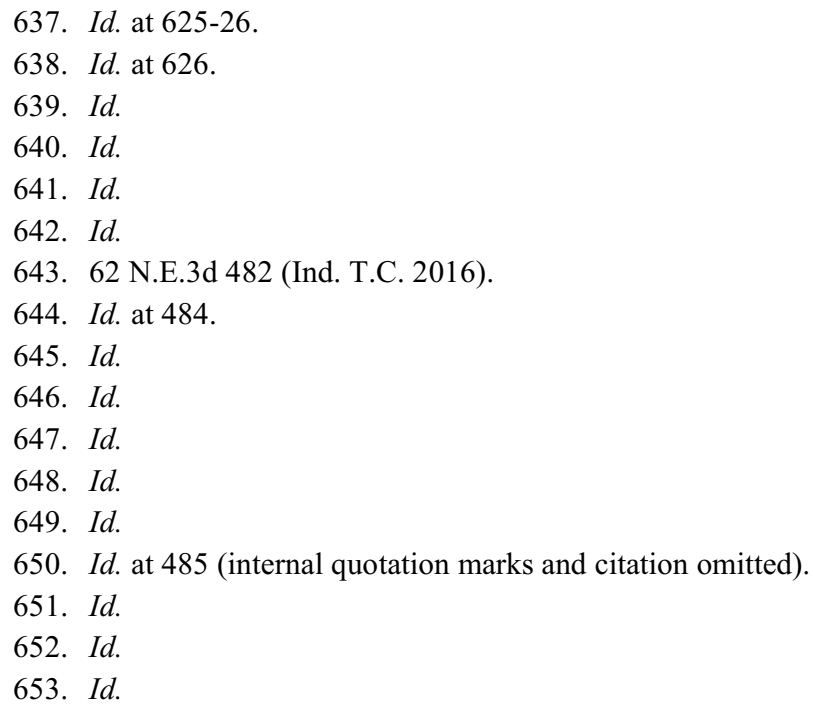


parentis"-which resulted in Robert and Claudia being treated as Class A transferees in computing the inheritance tax liability. ${ }^{654}$ The probate court accepted the Estate's inheritance tax return on September 30, 2011. ${ }^{655}$ In January of 2012, the Department filed, a "Petition for Rehearing and Redetermination of Inheritance Tax." ${ }^{\circ 56}$ The Department claimed the Estate owed an additional $\$ 512,919.68$ in inheritance tax, plus interest, because Robert and Claudia should have been classified as Class $C$ transferees. ${ }^{657}$ The probate court denied the Department's petition. ${ }^{658}$ The Department appealed to the Tax Court. ${ }^{659}$

On appeal, the Department argued the probate court erred in finding Rauch had an in loco parentis relationship-which resulted in the probate court improperly granting Robert and Claudia Class A transferee status. ${ }^{660}$ The Department reasoned Rauch never took the place of their parents or assumed any legal right or duties ${ }^{661}$ Further, the Department argued "the facts show[ed] that Orville was their friend, not a parent." ${ }^{662}$ The Tax Court explained the "[Indiana] Supreme Court clearly instructed that the focus in determining whether an in loco parentis relationship exists is the intent of the testator." ${ }^{\prime 663}$ Because the probate court found Rauch considered himself to be in the role of a father to Robert and Claudia, the probate court's findings were not inconsistent with the meaning of the term in loco parentis. ${ }^{664}$

The Department further argued the relationship Rauch had with Robert and Claudia was that of a friend and not a parent. ${ }^{665}$ The Department reasoned that neither Robert nor Claudia had lived with Rauch, they both maintained close relationships with their natural parents, and Rauch had no legal authority over them. ${ }^{666}$ However, the Tax Court stated that " $[t]$ he Probate Court identified facts that clearly demonstrated Orville's intent to be a father to Robert and Claudia and his intent to assume obligations of a parent by financially providing for them." ${ }^{1667}$ As such, the Tax Court affirmed the probate court's order that an in loco parentis relationship existed, and Robert and Claudia were properly classified as Class A transferees. ${ }^{668}$

654. Id.

655. Id.

656. Id. (internal quotation marks and citation omitted).

657. Id.

658. Id. at 486. "[T]he Department [also] filed a Motion to Correct Error with the Probate Court, which was subsequently denied." Id.

659. Id.

660. Id. at 487 .

661. Id.

662. $I d$.

663. Id. at 488 .

664. Id.

665. Id. at 489 .

666. Id.

667. Id.

668. Id. 